\title{
Erzurum İli Temel Coğrafi Özellikleri ve Potansiyel İşlemeli Tarım Alanı Varlığı
}

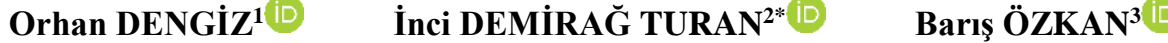 \\ ${ }^{1}$ Ondokuz Mayıs Üniversitesi, Ziraat Fakültesi, Toprak Bilimi ve Bitki Besleme Bölümü, Samsun, Türkiye \\ ${ }^{2}$ Giresun Üniversitesi, Fen Edebiyat Fakültesi, Coğrafya Bölümü, Giresun, Türkiye \\ ${ }^{3}$ Ondokuz Mayıs Üniversitesi, Mühendislik Fakültesi, Endüstri Mühendisliği, Samsun, Türkiye \\ (*Sorumlu yazar e-mail: dmrginci@ gmail.com) \\ DOI: 10.17097/ataunizfd.485163
}

Geliş Tarihi (Received Date): 19.11.2018

Kabul Tarihi (Accepted Date): 05.02.2019

\begin{abstract}
ÖZ: Bu çalışmanın temel amacı, güncel veriler kullanarak Erzurum ilinin temel coğrafi özelliklerinin belirlenmesi ile, analitik hiyerarșik süreç AHP-Fuzzy yaklașımı ve CBS ortamında bindirme analiz yöntemleri ile işlemeli tarım faaliyetlerine uygun potansiyel tarım alanlarının belirlenmesini içermektedir. Yaklaşı $25.000 \mathrm{~km}^{2}$ yüz ölçümüne sahip Erzurum iline ait işlemeli tarıma uygun potansiyel sahaların belirlenmesine yönelik olarak eğim, derinlik, erozyon, ana materyal olmak üzere dört adet arazi özelliği ve organik madde, hacim ağırlı̆̆ kullanılmıştır. Yükselti ve eğim özelliklerinin belirlenmesi amacıyla $10 \mathrm{~m}$ piksel çözünürlüklü sayısal yükseklik modeli (SYM), sayısal jeoloji ve toprak haritaları, CORINE arazi kullanım arazi örtüsü, uzun yıllara ait meteorolojik veriler ile alandan alınan 329 adet toprak örnekleri kullanılmıştır. Elde edilen sonuçlara göre, toplam il sınırına ait alanın \%19.64’ü işlemeli tarıma S1 ve $\mathrm{S} 2$ düzeylerinde yani çok uygun ve uygun olarak belirlenirken, $\% 49.45$ 'i ise işlemeli tarımsal faaliyetlere uygun olmadığı (N) belirlenmiștir.
\end{abstract}

Anahtar Kelimeler: Fuzzy-AHP, Potansiyel işlemeli tarım alanları, Erzurum

\section{Basic Geographical Properties and Determination of Potential Arable Lands of Erzurum} Province

\begin{abstract}
The main aim of the current study was to determine basic geographic properties and potential arable lands of Erzurum province using the AHP-Fuzzy approach and GIS overlaying analysis by taking into consideration of current data. In order to detect potential arable lands of Erzurum province which covers about $25000 \mathrm{~km}^{2}, 9$ criteria were used that four of them are slope, depth, erosion and parent material for land properties while, organic matter, bulk density, soil erosion, $\mathrm{pH}$, and calcium carbonate content were concerned as soil features. In this study, to generate slope and elevation, digital elevation model (DEM) which has $10 \mathrm{~m}$ pixel size was used. In addition, land use land cover, digital geology and soil maps, long term meteorological data and 329 soil samples were used. According to obtained results, it was found that $19.64 \%$ of the total area is highly suitable and suitable (S1 and S2) whereas, $49.45 \%$ of the it is not suitable $(\mathrm{N})$ for cultivation in the study area
\end{abstract}

Keywords: Fuzzy-AHP, Potential arable lands, Erzurum

\section{GİRIŞ}

Ülkemiz 'deki tarımsal arazi kullanımında yaşanan değişim incelendiğinde, özellikle Cumhuriyetin kuruluşundan sonra artan nüfusa paralel olarak tarıma açılan arazi miktarında yıllar itibarıyla önemli artış gerçekleştiği görülmektedir. 1928 yılında yaklaşık 6.6 milyon hektar alanda tarım yapılmakta iken, bu rakam 1950 yılında 25.3 milyon hektara, 1980'li yılların sonunda yaklaşık 28 milyon hektar seviyelerine ulaşmıștır. Fakat tarım arazilerinin büyüklük olarak son noktasına geldiği bu tarihten sonra azalmalar meydana gelmektedir. Bu durum özellikle günümüzde dahil olmak üzere tarım arazilerinin tarım dışı kullanımı hala sürmektedir. Türkiye'de son yılların verilerine göre toplam 78 milyon hektar yüzölçümünün yaklaşık \% 31'ine tekabül eden yaklaşık 24 milyon ha'lık kısmı tarım arazisi olarak değerlendirilmektedir (TÜİK, 2018).

Ülkemizde toprak ve arazilerimizin kullanımında önemli yanlışlıklar yapılmakta ve bunun sonucunda toprak ve arazi kaynaklarımızda geriye dönüşümü mümkün olamayacak şekilde kaybedilmektedir. Bu olumsuzlukların en önemli nedenlerinden birisi, toprakların binlerce y1ldır bulundukları ekolojik koşullar altında kazanmış oldukları karakteristiklerini dikkate alan planlama çalışmalarının olmayışı veya güncel olmayışıdır. Bu nedenle, günümüzde arazi kullanımına ilişkin kararların, iklim, bitki örtüsü, toprak ve diğer karakteristiklerin yorumlanarak en uygun kullanımların saptanması ve farklı araziler arasındaki kıyaslamalar yaparak doğru kullanımların belirlenmesi amacıyla yapılan arazi değerlendirme ve arazi kullanım planlaması çalışmaları sonuçlarına göre alınması artık zorunlu hale gelmiştir. Ayrıca, arazi kullanım haritaları, bir bölgede mevcut durumu gösteren önemli veri kaynaklarından birisidir. Özellikle yanlış kullanımların belirlenmesinde ve zamanla arazi kullanımında meydana gelen değişikliklerin izlenmesinde, arazi kullanım haritalarına öncelikle ihtiyaç duyulmaktadır (FAO, 1989).

Türkiye sahip olduğu iklim rejimi özellikleri ve aktif topoğrafik yapısıyla Dünyanın arazi bozulumu/çölleşme riski taşıyan ülkeleri arasında yer 
almaktadır. Erozyon başta olmak üzere insan kaynaklı arazi bozulumu/çölleşme bakımından da doğal ve kültürel kaynaklarımız ciddi tehditler altındadır. Erzurum Ovası'nda yer alan tarım topraklarının son 30 yıllık dönemdeki amaç dış1 kullanım boyutunu ortaya koyabilmek amaciyla yapılan çalışmada; Erzurum Ovası'nda toplam 27150 da tarım arazisinin tarımsal faaliyetler dışında kullanılmakta olduğu, bu arazilerin 17667 dekarının I. sınıf, 5422 dekarının II. sınıf ve 4061 dekarının ise III. sınıf arazi niteliğinde olduğu belirlenmiş ve tarımsal amaç dışı kullanılan arazilerden meydana gelen yıllık tarımsal gelir kaybının yaklaşık 2,5 milyon dolar olduğu tahmin edilmektedir (Özbek ve Öztaş, 2004). Yine, Dengiz ve Sarığlu (2011) Samsun ilinin potansiyel tarım arazilerinin dağılımlarının belirlenmesi amacıyla yaptıkları çalışma sonucuna göre, İlin \% 72.4'lük gibi çok büyük kısmının düşük potansiyel tarım alanlarını oluştururken, toplam alanın sadece \%14.2'lik gibi küçük bir kısmı tarımsal potansiyeli yüksek alanları oluşturduğunu belirlemişlerdir.
$\mathrm{Bu}$ çalışma ile güncel veriler kullanarak Erzurum ilinin temel coğrafi özelliklerinin belirlenmesi ve AHP-Fuzzy ve CBS ortamında bindirme analiz yöntemi ile işlemeli tarım faaliyetlerine uygun potansiyel sahaların belirlenmesini içermektedir. Ayrıca 1980'li yıllarda yapılmış Erzurum il arazi varlığı kapsamında yer alan arazi yetenek sınıflaması kapsamında işlemeli tarıma uygun alanlar ile karşılaştırılmanın yapılması amaçlanmıştır.

\section{MATERYAL VE METOT}

\section{Araștırma alanı coğrafi özellikleri}

Erzurum ili $40^{\circ} 14^{\prime} 15^{\prime \prime}$ ve $42^{\circ} 33^{\prime} 35^{\prime \prime}$ doğu boylamları ile $40^{\circ} 54^{\prime} 57^{\prime \prime}$ ve $39^{\circ} 06^{\prime} 10^{\prime \prime}$ kuzey enlemleri arasında ve yaklaşık $25.000 \mathrm{~km}^{2}$ yüz ölçümüne sahiptir (Şekil 1). Erzurum ilinin 19 ilçesi (Aşkale, Ilıca, Merkez, Köprüköy, Pazaryolu, Uzundere, Çat, Hınıs, Horasan, İspir, Karaçoban, Karayazı, Narman, Oltu, Olur, Pasinler, Şenkaya, Tekman, Tortum) bulunmaktadır.

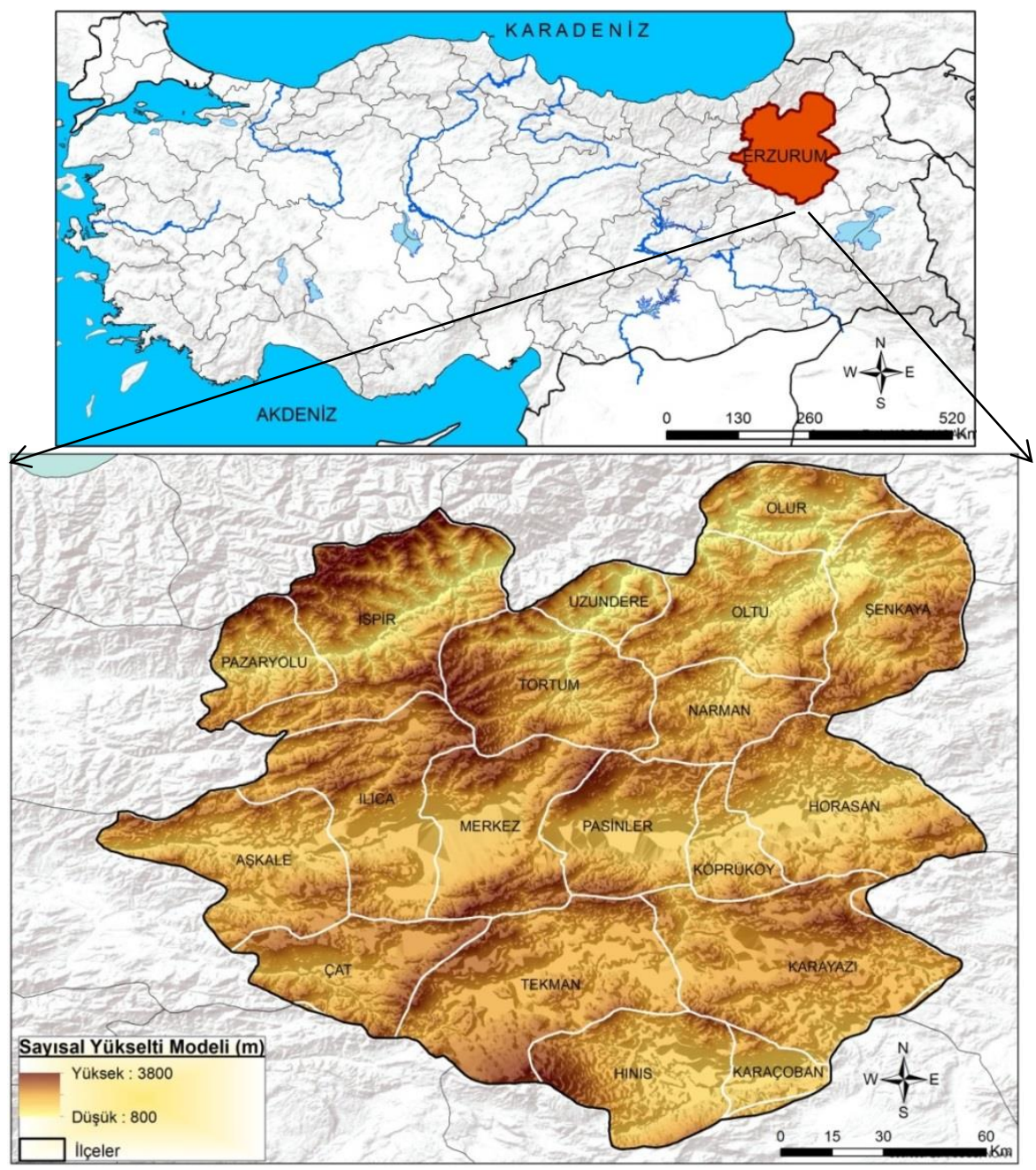

Şekil 1. Erzurum ili ve ilçelerine ait lokasyon haritası. 
İl deniz seviyesinden yaklaşı $1 \mathrm{k} 800 \mathrm{~m}$ ile $3800 \mathrm{~m}$ arasında olup, yeryüzü şekilleri bakımından \%63.7 dağlar (Rize Dağları, Kuzey Anadolu Dağları, Karasu-Aras Dağları), \%4 ovalar (Erzurum Ovas1, Pasinler Ovası, Hınıs Ovası), \%12.2 yaylalar, \%20

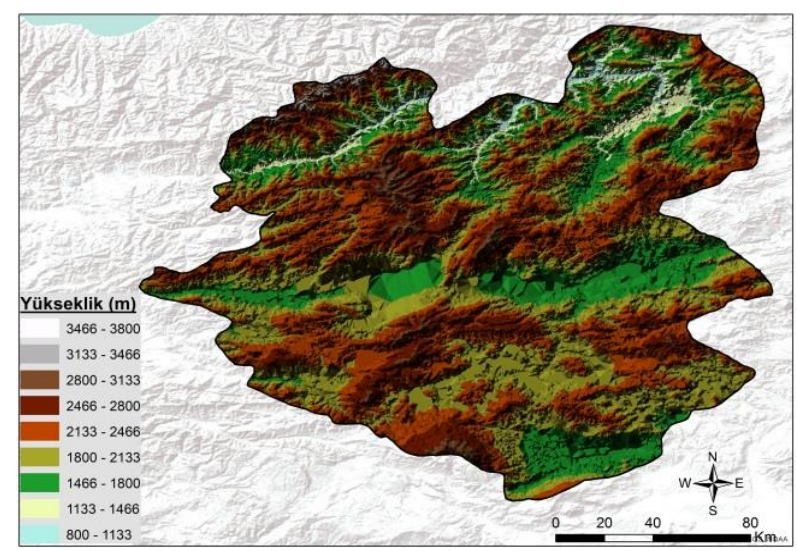

Şekil 2. Erzurum İli yükselti ve eğim haritaları

İlin CORINE-2012 arazi kullanım arazi örtüsü sınıflaması Çizelge 1 ve Şekil 3 de verilmiştir. Çizelge 1'e göre yaklaşık \%56'sını mera alanlarını

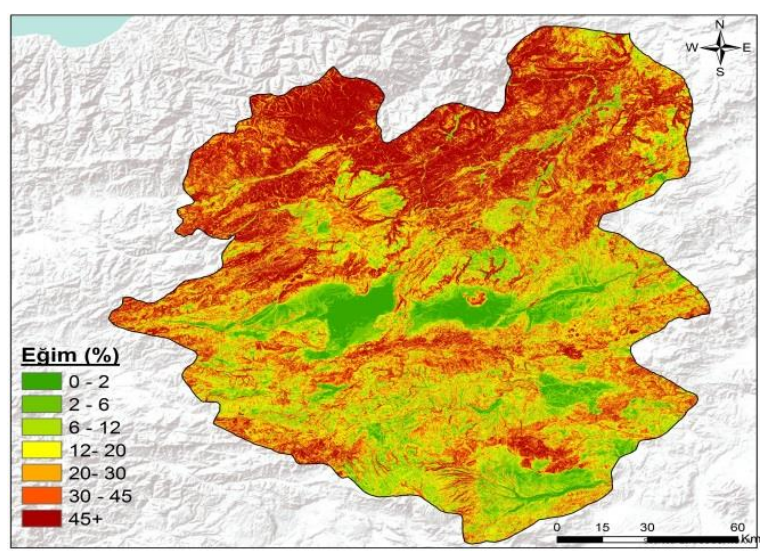

platolardan oluşmaktadır. Toplam İlin yaklaşık \%26.5 (656782.6 ha) alanı eğimi işlemeli tarım sınırı olan \%12'nin altında olan alanları oluşturmaktadır (Şekil 2).

oluştururken bunu yaklaşı $\% 11$ ile kuru tarım alanları oluşturmaktadır.

Çizelge 1. Erzurum ili CORINE-2012 arazi kullanım arazi örtüsü sınıflaması

\begin{tabular}{|l|l|l|}
\hline Arazi kullanım Arazi örtüsü & ha & $\%$ \\
\hline Orman & 125130,4 & 5,03 \\
\hline Çıplak Kayalık & 125009,7 & 5,03 \\
\hline Sürekli şehir & 9187,83 & 0,37 \\
\hline Kuru Tarım & 379685,9 & 15,27 \\
\hline Su Yolu ve bataklık & 16163,55 & 0,65 \\
\hline Meyveyle karışık sulu & 35076,24 & 1,41 \\
\hline Mera & 1390540 & 55,91 \\
\hline Bitki değişin alanları & 133197,2 & 5,36 \\
\hline Doğal bitki örtüsü birlikte tarım alanları & 269103,1 & 10,82 \\
\hline Endüstriyel/ticari birimler ve havaalanı & 3954,42 & 0,16 \\
\hline Toplam & 2487048 & 100,00 \\
\hline
\end{tabular}




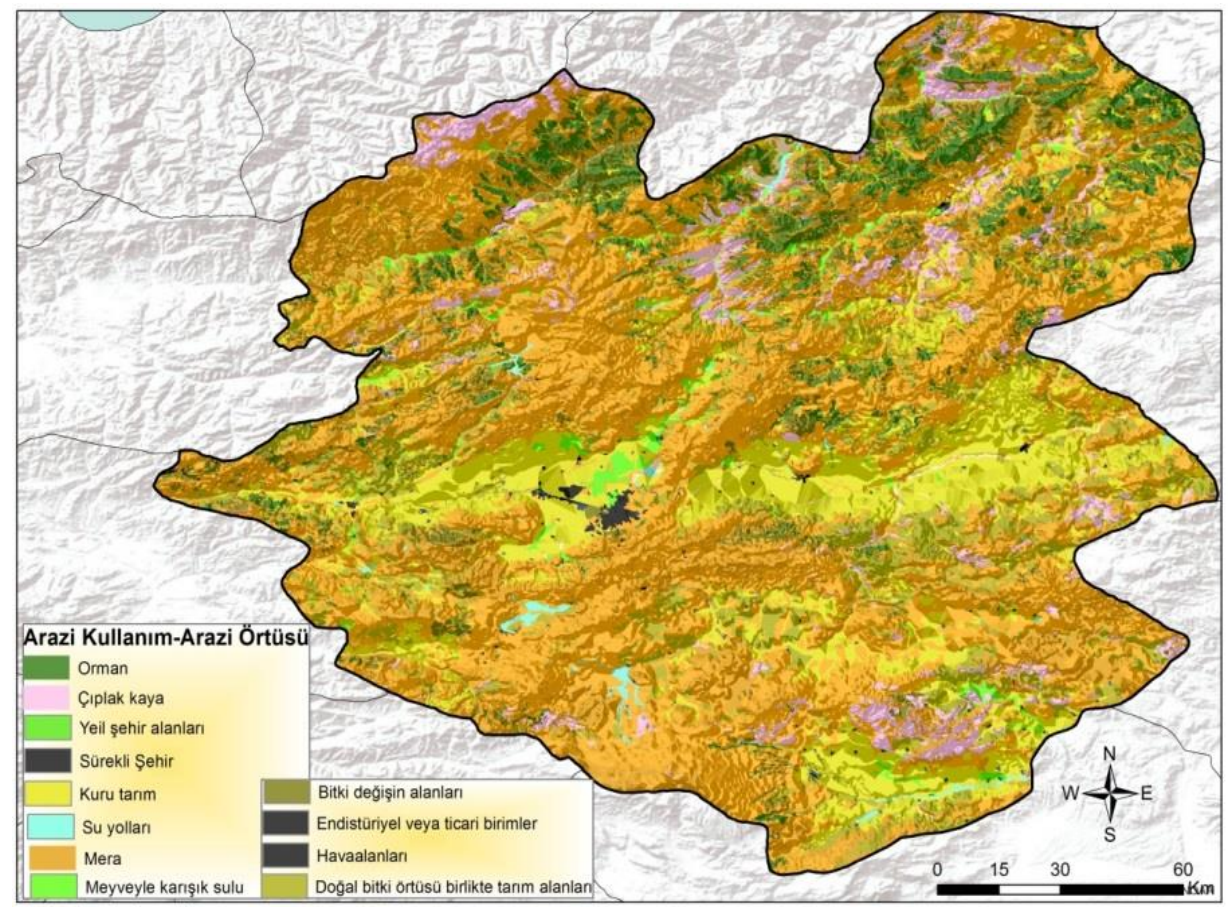

Şekil 3. Erzurum ili CORINE-2012 arazi kullanım arazi örtüsü sınıflaması

İlin büyük toprak grubu ve jeolojik materyal dağılımı ise Çizelge 2- 3 ve Şekil 4'de verilmiştir. Çizelge 2'ye göre yaklaşık \%38'ini bazaltik topraklar oluştururken bunu yaklaşık \%32 ile kestanerengi topraklar oluşturmaktadır. Jeolojik materyal olarak alanın \%25.6'sı kırıntılı sedimenter kayaçların (kil taşı, kum taşı, silt taş1 çakıl taşı, çamur taşı) oluşturduğu materyallerce dağılım gösterirken, bazikultrabazik magmatik kayaçlardan bazalt, gabro, serpantin ve peridodit materyalleri ise alanın \%19,3’ünde dağılım göstermektedir.

Çizelge 2. Erzurum İlinde dağılım gösteren büyük toprak gruplarının (BTG'lerin) alansal ve oransal dağılımları

\begin{tabular}{|l|l|l|}
\hline Büyük Toprak Grubu & ha & $\%$ \\
\hline Bazaltik Toprak & 944696,2 & 37,98 \\
\hline Kestanerengi toprak & 796746,6 & 32,04 \\
\hline Koluviyal toprak & 140986,6 & 5,67 \\
\hline Kahverengi Topraklar & 132606,2 & 5,33 \\
\hline Kahverengi Orman Toprakları & 184305,4 & 7,41 \\
\hline Alüvyal Topraklar & 77949,3 & 3,13 \\
\hline Kireçsiz Kahverengi Topraklar & 7456,02 & 0,30 \\
\hline Yüksek Dağ Çayır Topraklar & 35246,64 & 1,42 \\
\hline Kırmızımsı Kestanerengi Topraklar & 42394,56 & 1,70 \\
\hline Kireçsiz Kahverengi Orman Topraklar & 8133,84 & 0,33 \\
\hline Hidromorfik Topraklar & 431,34 & 0,02 \\
\hline Organik Topraklar & 369,72 & 0,01 \\
\hline Tuzlu-Alkali ve Tuzlu-Alkali Karışı̆̆ı Toprakları & 369,72 & 0,01 \\
\hline Gri Kahverengi Podzolik Topraklar & 246,48 & 0,01 \\
\hline Diğer & 115106,2 & 4,63 \\
\hline Toplam & 2487045 & 100,00 \\
\hline
\end{tabular}


Çizelge 3. Erzurum İlinde dağılım gösteren jeolojik materyaller

\begin{tabular}{|l|l|l|l|l|l|}
\hline Jeoloji Materyal & ha & $\%$ & Jeoloji Materyal & ha & $\%$ \\
\hline Aglomera & 93275,3 & 3,7 & Kiltaş1 & 21840,1 & 0,9 \\
\hline Alüvyon & 196456,6 & 7,9 & Kirę̧taş1 & 97014,9 & 3,9 \\
\hline Andezit & 333979,6 & 13,4 & Kumtaş1 & 342330,6 & 13,8 \\
\hline Bazalt & 417217,8 & 16,8 & Melanj & 81048,6 & 3,3 \\
\hline Breş & 3171,1 & 0,1 & Mermer & 19327,7 & 0,8 \\
\hline Çakıltaş1 & 258335,1 & 10,4 & Ofiyolit & 28647,1 & 1,2 \\
\hline Çamurtaş1 & 11047,7 & 0,4 & Peridodit & 46206 & 1,9 \\
\hline Çört & 50043,1 & 2,0 & Proklastik & 108412 & 4,4 \\
\hline Dasit & 3811,5 & 0,2 & Serpantin & 3691,7 & 0,1 \\
\hline Dayk & 8395,1 & 0,3 & Siltaş1 & 3336,7 & 0,1 \\
\hline Diabaz & 649,3 & 0,0 & Şist & 27118,5 & 1,1 \\
\hline Evporit & 924,9 & 0,0 & Şely & 384,4 & 0,0 \\
\hline Gabro & 11772,5 & 0,5 & Traverten & 9172,1 & 0,4 \\
\hline Granit & 78933,2 & 3,2 & Tüf & 17157,5 & 0,7 \\
\hline Jips & 5350,5 & 0,2 & Volkanit & 157557,1 & 6,3 \\
\hline Yamaç Moloz & 45884,8 & 1,8 & Olistostrom & 4942,6 & 0,2 \\
\hline
\end{tabular}
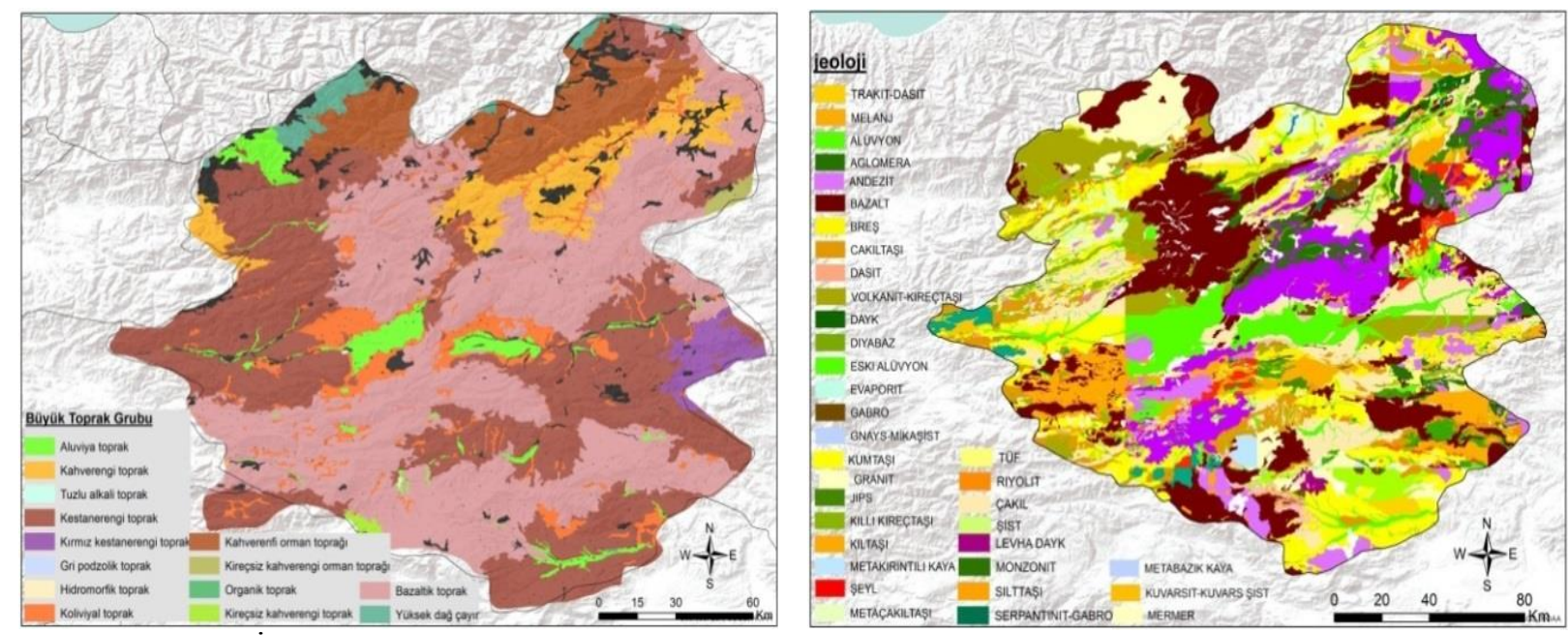

Şekil 4. Erzurum İlinde dağılım gösteren büyük toprak grupları ve jeoloji haritası

Erozyonun konumsal olarak miktarının tahmin edilmesinde RUSLE (Revised Universal Soil Loss Equation) modeli kullanılmıştır. RUSLE modeli su erozyonu ton/ha/yıl olarak toprak kaybı potansiyelini, iklim, toprak, topografya ve arazi kullanım ve örtüsünün ölçülebilir ve hesaplanabilir parametrelerinden niceliksel olarak (ton $\mathrm{ha}^{-1} \mathrm{yll}^{-1}$ ) değerlendirmektedir (Wischmeier and Smith 1978, Renard et al., 1997). Buna göre Erzurum ilinin ton $\mathrm{ha}^{-1} \mathrm{y}^{-1}{ }^{-1}$ olarak toprak kaybına ait sinıflar ve haritas 1 Çizelge 4 ve Şekil 5'de verilmiştir. İlin \%20.9'da şiddetli ve çok şiddetli erozyon tehlikesi bulunurken, $\% 67.6$ 'sında ise hafif veya çok az erozyon riski taşıdığı görülmektedir. 
Çizelge 4. Erzurum ili RUSLE modeline göre toprak erozyon kaybı sınıfları

\begin{tabular}{|l|c|c|c|}
\hline Sinıf (ton/ha/yll) & Tanımlama & ha & $\%$ \\
\hline $1: 0-5$ & Hafif veya hiç yok & 1681338 & 67,6 \\
\hline $2: 5-10$ & Orta & 286499,5 & 11,5 \\
\hline $3: 10-20$ & Şiddetli & 216727,6 & 8,7 \\
\hline $4: 20+$ & Çok Şiddetli & 302476,9 & 12,2 \\
\hline Toplam & & 2487042 & 100,0 \\
\hline
\end{tabular}

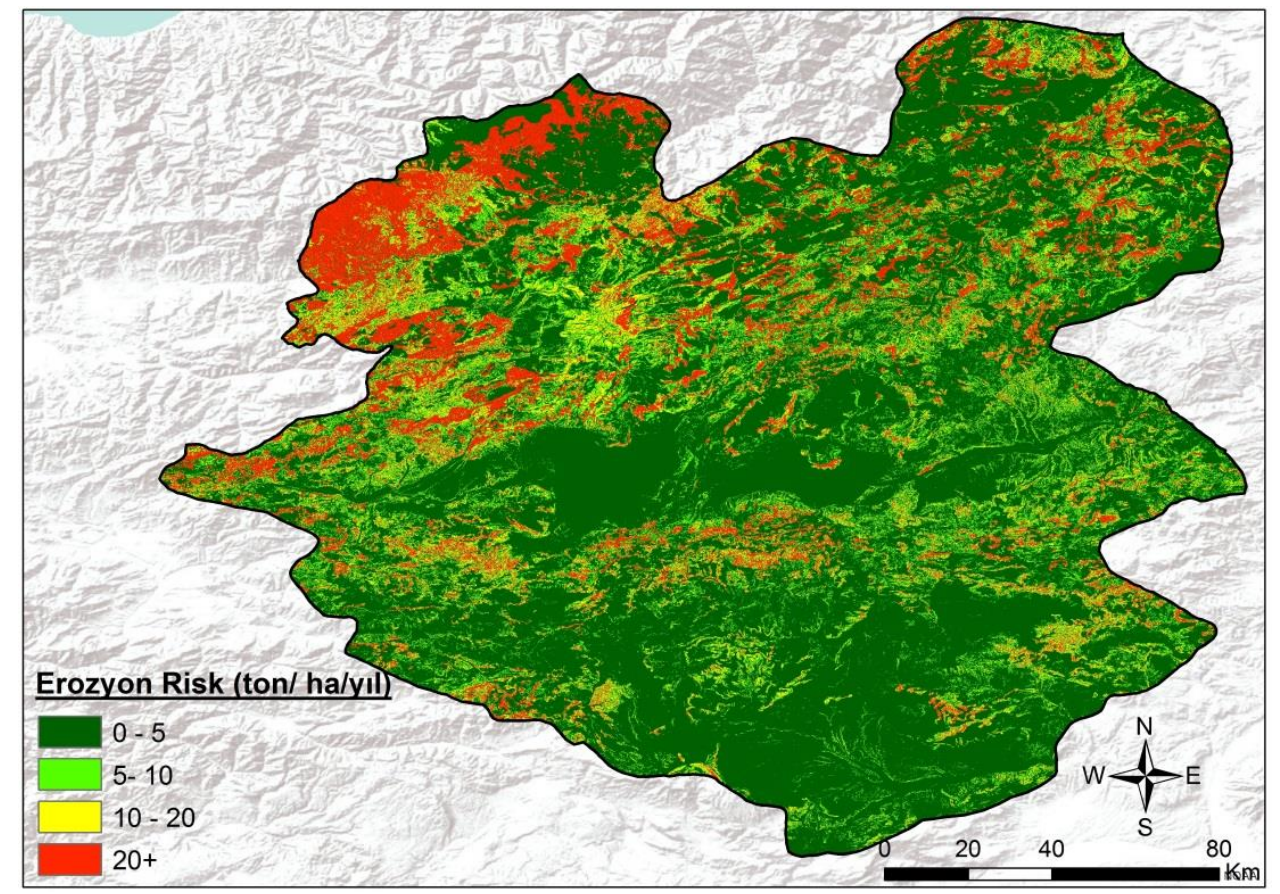

Şekil 5. Erzurum ili RUSLE modeline göre toprak erozyon kaybı haritası

İlin uzun yllar meteorolojik verisine göre (1929-2017) en soğuk ay ortalamas1, $-8.6^{\circ} \mathrm{C}$, en sicak ay ortalaması $19.6^{\circ} \mathrm{C}$, en düşük sıcaklık $-35^{\circ} \mathrm{C}$ ve en yüksek sıcaklık ise, $35^{\circ} \mathrm{C}$ olarak ölçülmüsşür. Yıllık yağış tutarı $453 \mathrm{~mm}$ kadardır. En az yă̆ı̧ kış devresinde düşer. $\mathrm{Bu}$ devrenin yağışları kar biçiminde olup, kar yağışlı gün sayısı 50 ve kar örtüsünün yerde kalış süresi ise 114 gün kadardır. En yağışlı devre ilkbahar ve yaz mevsimleridir. Yıllık nispi nem ortalaması $\% 63$ civarında olup en düşük nem oranı \%46 ile Ağustos ayıdır. Erzurum'un hakim rüzgar yönü güneybatı ve güney doğudur.
Erzurum iline ait uzun yıllar meteorolojik verilere sahip olan yedi ilçenin Newhall modeline (Newhall and Berdanier, 1994; Van Wambeke, 2000) göre ilin $20 \mathrm{~cm}$ ve $100 \mathrm{~cm}$ toprak derinliklerinde toprak nem ve sicaklık rejimleri Çizelge 5'de verilmiştir. Çizelge 5'e göre sıcaklı rejimi Erzurum'da Mesic olarak belirlenmiştir. Nem rejimleri ise toprağın sı ̆ olduğu $20 \mathrm{~cm}$ derinlikte Typic Aridic olarak sinıflandırılırken, derin olan (100 $\mathrm{cm}$ derinlik) durumlarda Hınıs, Horasan ve İspir Dry Xeric diğer İlçeler (Merkez, Oltu, Olur ve Pasinler) ise Typic Xeric olarak sınıflandırılmıştır. 
Çizelge 5. Erzurum Merkez ve İlçelere ait Newhall modeline göre nem ve sıcaklık rejimleri

\begin{tabular}{|l|l|c|c|c|c|}
\hline \multirow{2}{*}{ İstasyon Ad1 } & \multirow{2}{*}{ Sicaklık Rejimi } & \multicolumn{2}{|c|}{ Nem Rejimi $(20 \mathrm{~cm}$ toprak $)$} & \multicolumn{2}{c|}{ Nem Rejimi $(100 \mathrm{~cm}$ toprak $)$} \\
\cline { 3 - 6 } & & Grup & Alt Grup & Grubu & Alt Grup \\
\hline Merkez & Mesic & Aridic & Typic Aridic & Xeric & Typic Xeric \\
\hline Hınıs & Mesic & Aridic & Typic Aridic & Xeric & Dry Xeric \\
\hline Horasan & Mesic & Aridic & Typic Aridic & Xeric & Dry Xeric \\
\hline İspir & Mesic & Aridic & Typic Aridic & Xeric & Dry Xeric \\
\hline Oltu & Mesic & Aridic & Typic Aridic & Xeric & Typic Xeric \\
\hline Olur & Mesic & Aridic & Typic Aridic & Xeric & Typic Xeric \\
\hline Pasinler & Mesic & Aridic & Typic Aridic & Xeric & Typic Xeric \\
\hline
\end{tabular}

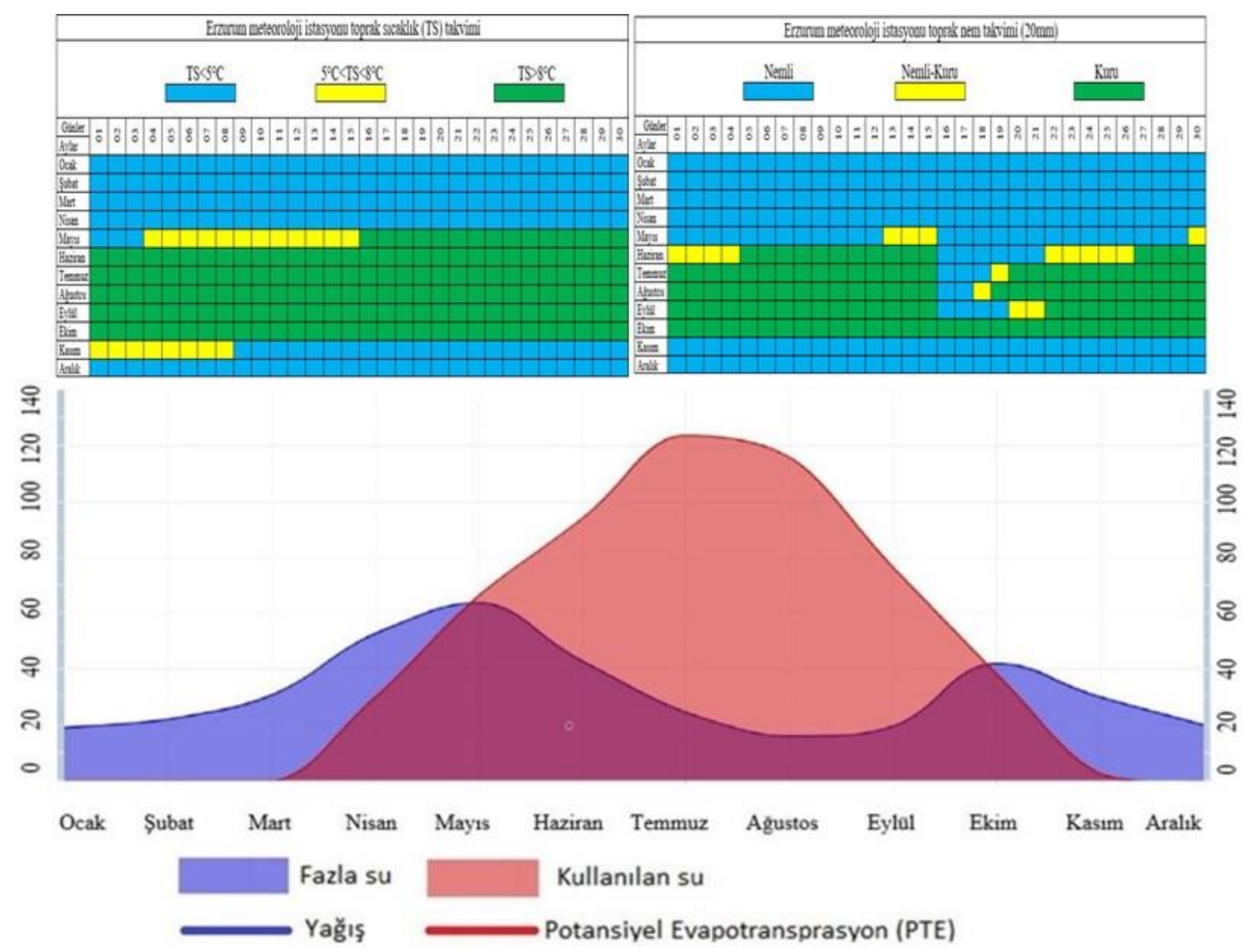

Şekil 6. Erzurum İli merkez ilçesine ait Newhall modeline nem ve sıcaklık takvimi ile toprak su bilanço diyagram 1

Toprak örneklemeleri ve enterpolasyon işlemleri

Çalışma alanından 0-30cm derinlikten 329 adet koordinatlı toprak örneklemesi yapılmıştır (Şekil 7). Alınan toprak örnekleri farklı enterpolasyon modelleri kullanılması suretiyle en uygun model belirlenerek alanın toprak parametrelerine (kil, silt, kum, pH, HA, kireç ve organik madde) ait dağılım haritası üretilmiştir. 


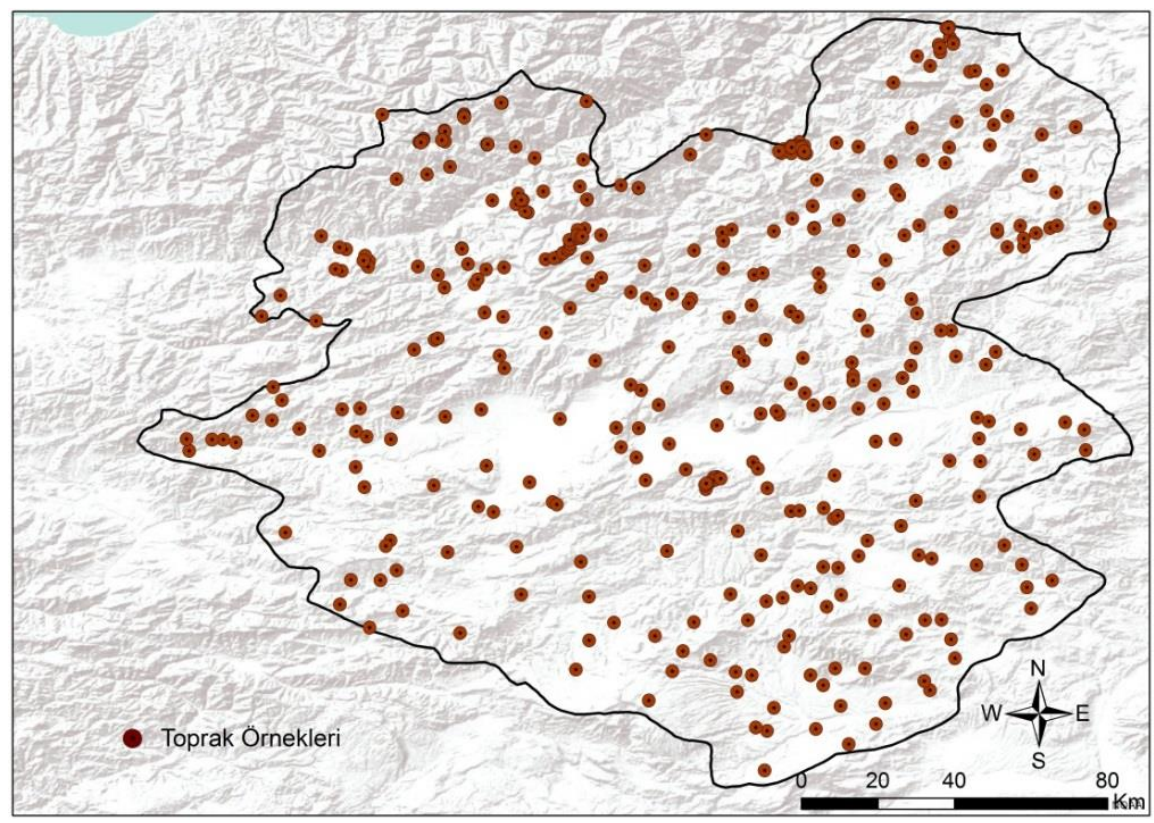

Şekil 7. Çalışma alanına ait toprak örneklemesi

Enterpolasyon teknikleri çalışılan özelliklerin değerlerini mesafeye bağlı değişkenliklerinin ifade edilmesinde ve haritalanmasinda kullanılır (Goovaerts, 1998; Mulla and McBratney, 2000). Haritalama öncesi verilerin normal dağılım göstermeyenleri özelliklere uygun dönüşümler yapılmıştır. Toprak parametrelerinin değerinin alansal dağılımının belirlenmesinde en çok kullanılan enterpolasyon yöntemlerinden IDW, RBF (Spline) deterministik yöntemler ile stokastik yöntemlerden de (temelde Kriging olarak da bilinmektedir) doğal (ordinary), evrensel (universal), basit (simple) kriging yöntemleri kullanılmıştır. Yöntemlerin karşılaştırılmalarında ölçülen değerler ve tahmin edilen değerler arasındaki ilişkiyi sorgulayabilmek, ölçülen değerlere en yakın sonucu veren başka bir ifade ile yöntemler arasından en uygun olanının seçebilmek için literatürde farklı karşılaştırma yöntemlerinin dikkate alındığı görülmektedir (Taşan ve Demir, 2017; Arslan vd., 2012). Genel anlamda en yaygın kullanılan yöntemler; karekök ortalama hata (RMSE), ortalama mutlak hata (MAE), yöntemlerdir. $\mathrm{Bu}$ çalışma için RMSE seçilerek, enterpolasyonda kullanılan on beş yöntem (Ters Mesafe Ağırlıklandırma (IDW); 1,2,3, Radyal Tabanlı Fonksiyon (RBF); Thin Plate Spline, Completely Regularized Spline, Spline With Tension, Kriging; Doğal (Ordinary), Basit (Simple), Evrensel (Üniversal) karşılaştırılacaktır. En düşük karekök ortalama hata değerini veren yöntem, en uygun yöntem olarak değerlendirilecektir. Karekök ortalama hatanın hesaplanmasında Eşitlik 1 kullanılmıştır.

Eşitlikte; $\mathrm{RMS}=\sqrt{\frac{\sum\left(z_{i}-z_{i}\right)^{2}}{n}}$

RMSE: karekök ortalama hata $Z_{i}$ : tahmin edilen değer, $Z_{i} *$ ölçülen değer ve $n$ örnek sayısını ifade etmektedir.

Her bir toprak örnekleme yapılan noktadaki toprak özelliklerinin en büyük, en küçük, standart sapma, varyasyon katsayısı, ortalama, çarpıklık ve basıklık değerleri şeklindeki ait tanımlayıcı parametreler SPSS programı yardımı ile hesaplanmıştır.

\section{Değerlendirme kriterleri}

Erzurum ilinin potansiyel işlemeli tarıma uygun alanların belirlenmesine yönelik olarak çalışmada eğim, derinlik, erozyon, ana materyal olmak üzere dört adet arazi özelliği ve O.M, H.A, bünye, $\mathrm{pH}$ ve kireç olmak üzere beş adet toprak özelliği toplamda 9 adet kriter kullanılmıştır. Ayrıca her bir kritere ait sınıflar oluşturulmuş ve bu sınıfların her bir için işlemeli tarımsal faaliyetlere uygunluk sınıflar için 1 ile 4 arasında ağırlık değerleri verilmiştir. Kriter sınıfları potansiyel işlemeli tarım yapılabilmesine optimum uygunluk seviyesindeyse 1, düşük uygunluk seviyesinde ise 4 değerini almaktadır. $\mathrm{Bu}$ iki değer arası ise sınıflandırıcı faktör ve derecesine göre değerlendirilmiştir (Çizelge 6). 
Çizelge 6. Potansiyel ekim alanlarının değerlendirmesinde kullanılan kriterler, kriter sınıfları ve sınıf değerleri

\begin{tabular}{|c|c|c|c|c|c|c|c|c|c|c|c|}
\hline \multicolumn{12}{|c|}{ Değerlendirme kriterleri } \\
\hline \multicolumn{6}{|c|}{ Ana materyal } & \multicolumn{2}{|c|}{ Erozyon (ton/ha/yıl) } & \multicolumn{2}{|c|}{ Derinlik (cm) } & \multicolumn{2}{|c|}{ Eğim (\%) } \\
\hline \multicolumn{5}{|c|}{ Sinif } & Değer & \begin{tabular}{l|l} 
Sinif & \\
\end{tabular} & Değer & \begin{tabular}{l|l} 
Sinif &
\end{tabular} & Değer & Sinif & Değer \\
\hline \multicolumn{5}{|c|}{ Genç aluviyon birikinti } & 1 & $0-5$ & 1 & $0-20$ & 1 & $0-2$ & 1 \\
\hline \multicolumn{5}{|c|}{$\begin{array}{l}\text { Bazik-ultrabazikmağmatik ve püskürükler, } \\
\text { melanj, ofiyolitik ve serpantin, şeyl, vb. şist, } \\
\text { fillit gibi başkalaşmış kayaçlar, kil taşı, } \\
\text { marn }\end{array}$} & 2 & $5-10$ & 2 & $20-50$ & 2 & $2-6$ & 2 \\
\hline \multicolumn{5}{|c|}{$\begin{array}{l}\text { Silt taşı, çamur taşı, konglomera, traverten, } \\
\text { kireç taşı, dolomit, mermer }\end{array}$} & 3 & $10-20$ & 3 & $50-90$ & 3 & $6-12$ & 3 \\
\hline \multicolumn{5}{|c|}{$\begin{array}{l}\text { Asit magmatikler, çört, gnays, kumullar, } \\
\text { volkanik küller, tüf, aglomera, breş, } \\
\text { evaporitler, çakıl taş1 kum taş1 }\end{array}$} & 4 & $>20$ & 4 & $>90$ & 4 & $>12$ & 4 \\
\hline \multicolumn{12}{|c|}{ Değerlendirme kriterleri } \\
\hline \multicolumn{2}{|c|}{ O.M. (\%) } & \multicolumn{2}{|c|}{ HA } & \multicolumn{3}{|c|}{ Bünye } & & \multicolumn{2}{|c|}{$\mathrm{pH}$} & \multicolumn{2}{|c|}{ Kireç (\%) } \\
\hline Sinif & Değer & Sinif & Değer & \multicolumn{3}{|c|}{ Sinif } & Değer & Sinif & Değer & Sinif & Değer \\
\hline$>3$ & 1 & $1-1.2$ & 1 & \multicolumn{3}{|c|}{ Orta (L, Si, SiL, fSL) } & 1 & $6.5-7.5$ & 1 & $0-5$ & 1 \\
\hline $3-2$ & 2 & $1.2-1.4$ & 2 & \multicolumn{3}{|c|}{ Ortaİnce $(\mathrm{C}<\% 45, \mathrm{CL}, \mathrm{SiL}, \mathrm{SCL})$} & 2 & $5.5-6.5$ & 2 & $5-10$ & 2 \\
\hline $2-1$ & 3 & $1.4-1.55$ & 3 & \multicolumn{3}{|c|}{ Çokİnce (fC $>\% 45, \mathrm{SiCL}, \mathrm{SC})$} & 3 & $7.5-8.5$ & 3 & $10-20$ & 3 \\
\hline $0-1$ & 4 & $>1.55$ & 4 & \multicolumn{3}{|c|}{ Kaba (S, SL, LS) } & 4 & $<5.5->8.5$ & 4 & $>20$ & 4 \\
\hline
\end{tabular}

\section{Fuzzy-AHP yaklaşımı}

Analitik Hiyerarşi Prosesi (AHP), Thomas L. Saaty tarafindan geliştirilen literatürde sıklıkla kullanılan çok amaçlı karar verme yöntemlerinden birisidir. AHP karar almada, grup veya bireyin önceliklerini de dikkate alan, nitel ve nicel değişkenleri bir arada değerlendiren matematiksel bir yöntemdir (Saaty, 1980). AHP yöntemi, gerçek hayatta birçok karar verme probleminin çözümünde etkin bir biçimde kullanılmasına rağmen, ikili karşılaştırmalar yaparken kesin sayılar kullanmasından dolayı eleştirilmektedir (Dağdeviren, 2007). Ayrıca belirsizlik ve kararsızlık durumlarını ele almada yetersiz olması (Deng, 1999) ve uzman kişinin bilgilerini ele alsa da, insani düşünme tarzını yansitamamas1 (Kahraman vd., 2003) nedenlerinden dolayı da eleştirilmektedir. Yöntemin karar verme konusundaki bu eksikliklerinin önüne geçmek amacıyla yöntem bulanık mantık ile entegre edilerek Bulanık Analitik Hiyerarşi Prosesi (BAHP) yöntemi ortaya konmuştur. Literatürde çeşitli yazarlar tarafından ortaya konulan farklı BAHP yöntemleri bulunmaktadır. Bulanık AHP'ye ilişkin ilk çalışma üçgen bulanık sayılar kullanılarak, bulanık oranları kıyaslayan Van Laarhoven and Pedrycz (1983) tarafından yapılmıştır. Daha sonra Buckley (1985), yamuk bulanık sayıları kullanarak bir model geliştirmiştir. Chang (1996), BAHP'nin ikili karşılaştırma ölçeği için üçgen bulanık sayıları ve ikili karşılaştırmaların yapay mertebe değerleri için mertebe analizi yöntemini kullanarak BAHP'nin ele alınmasında yeni bir yaklaşım ortaya koymuştur.
Bulanık küme kavramı, ilk kez Lotfi A. Zadeh tarafindan 1965 y1lında "Bulanık Kümeler" adlı makalenin yayınlanması ile ortaya atılmışır. Bulanık küme, devamlı üyelik derecesine sahip nesneler kümesidir. Bulanık küme, her nesneyi 0 ile 1 arasında değişen üyelik derecesine sahip üyelik fonksiyonu ile nitelendirmektedir (Zadeh, 1965).

$\mathrm{Bu}$ çalışmada potansiyel işlemeli tarım sahalarının uygunluklarının siralanmasında kullanılacak kriterlerin göreceli önem seviyelerinin belirlenmesinde karşılaşılacak sözel belirsizliğin daha iyi ifade edilmesi amaci ile Chang (1996) tarafindan ortaya konulan mertebe analizi yöntemi kullanılmıştır. Chang (1996), yaptığı çalışmada BAHP'de ikili karşılaştırması alaları için üçgensel bulanık sayıları kullanmıştır.

Bir üçgen bulanık sayı $(1|\mathrm{~m}, \mathrm{~m}| \mathrm{u})$ veya $(1, \mathrm{~m}$, u) şeklinde gösterilir (Kahraman, 2004). Bir bulanık olay için $1, \mathrm{~m}$ ve u parametreleri, sırasıyla mümkün en küçük değeri, en çok beklenen değeri ve mümkün en büyük değeri temsil eder. Her üçgen bulanık sayının lineer gösterimleri sol ve sağ taraf şeklinde Eşitlik (2)'deki üyelik fonksiyonu ile tanımlanabilir (Kahraman, 2004):

$\mu(x \mid \widetilde{M})=\left\{\begin{array}{cr}0, \quad x<l, & \\ (x-l) /(m-l), & l \leq x \leq m, \\ (u-x) /(u-m), & m \leq x \leq u, \\ 0, & x>u .\end{array}\right.$

BAHP hesaplamalarında üçgen bulanık sayılar için temel aritmetik işlemlerine gerek duyulmaktadır. Aşağıda $\widetilde{M}_{1}=\left(l_{1}, m_{1}, u_{1}\right) \quad$ ve $\quad \widetilde{M}_{2}=\left(l_{2}, m_{2}, u_{2}\right)$ bulanık üçgen sayıları için temel aritmetik işlemler verilmiştir: 
Toplama $:\left(l_{1}+l_{2}, m_{1}+m_{2}, u_{1}+u_{2}\right)$

Çarpma: $\left(l_{1} \times l_{2}, m_{1} \times m_{2}, u_{1} \times u_{2}\right)$

Bölme : $\left(l_{1} / u_{2}, m_{1} / m_{2}, u_{1} / l_{2}\right)$

Negatif : $\left(-l_{1},-m_{1},-u_{1}\right)$

Tersi : $\left(1 / u_{1}, 1 / m_{1}, 1 / l_{1}\right)$

$\mathrm{Bu}$ tanımlama ve bilgilerden sonra BAHP algoritması aşağıdaki gibi verilebilir.

$\mathrm{Bu}$ yöntemde, her bir ölçüt alınır ve her bir amaç için mertebe analiz yapılır. $X=\left\{\mathrm{x}_{1}, \mathrm{x}_{2}, \ldots, \mathrm{x}_{\mathrm{n}}\right\}$ bir ölçüt kümesi ve $U=\left\{\mathrm{u}_{1}, \mathrm{u}_{2}, \ldots, \mathrm{u}_{\mathrm{n}}\right\}$ bir amaç kümesi olsun. Böylece her bir ölçüt için $m$ tane mertebe analiz değeri elde edilir. Bunlar $M_{g_{i}}^{1}$, $M_{g_{i}}^{2}, \ldots, M_{g_{i}}^{m} i=1,2, \ldots, n$ şeklinde gösterilir.

Burada belirtilen tüm $\mathrm{M}_{\mathrm{g}_{1}}^{1}$ parametreleri l, m ve u olan üçgensel bulanık sayıları göstermektedir. Chang'in mertebe analizi yaklaşımının aşamaları aşağıda verilmiştir (Chang, 1996):

Aşama 1: Ölçüt i’ye göre bulanık sentetik mertebe değeri Eşitlik (3)' de gösterildiği gibi tanımlanmaktadır.

$$
S_{i}=\sum_{j=1}^{m} M_{g_{i}}^{j} \otimes\left[\sum_{i=1}^{n} \sum_{j=1}^{m} M_{g_{i}}^{j}\right]^{-1}
$$

Eşitlik (1)' de yer alan $\sum_{j=1}^{m} M_{g_{i}}^{j}$ ifadesini elde etmek için, Eşitlik (4)' deki bulanık işlemin yapılması gerekmektedir

$$
\sum_{j=1}^{m} M_{g_{i}}^{j}=\left(\sum_{j=1}^{m} l_{j}, \sum_{j=1}^{m} m_{j}, \sum_{j=1}^{m} u_{j}\right)
$$

$\left[\sum_{i=1}^{n} \sum_{j=1}^{m} M_{g_{i}}^{j}\right]^{-1}$ ifadesini elde etmek için ise $M_{g_{i}}^{j} j=\{1,2, \ldots, m\}$ değerleri üzerinde bulanık toplama işlemi yapmak ve Eşitlik (5)' de verilen denklemdeki vektörün tersini hesaplamak gerekir. Tersi alınan vektör Eşitlik (6)’ de görülmektedir.

$$
\sum_{i=1}^{n} \sum_{j=1}^{m} M_{g_{i}}^{j}=\left(\sum_{i=1}^{n} l_{i}, \sum_{i=1}^{n} m_{i}, \sum_{i=1}^{n} u_{i}\right)
$$

$\left[\sum_{i=1}^{n} \sum_{j=1}^{m} M_{g_{i}}^{j}\right]^{-1}=\left(\frac{1}{\sum_{i=1}^{n} u_{i}}, \frac{1}{\sum_{i=1}^{n} m_{i}}, \frac{1}{\sum_{i=1}^{n} l_{i}}\right)(6)$

Adım 2. $M_{2}=\left(l_{2}, m_{2}, u_{2}\right) \geq M_{1}=$ $\left(l_{1}, m_{1}, u_{1}\right)$ ifadesinin olasilik derecesi $V=$ $\left(M_{2} \geq M_{1}\right)=\sup _{y \geq x}\left[\min \mu_{M_{1}}(x), \mu_{M_{2}}(x)\right\rfloor \quad$ şeklinde tanımlanır. Bu eşitliği açarsak;

$$
\begin{gathered}
V\left(M_{2} \geq M_{1}\right)=h g t\left(M_{2} \cap M_{1}\right)=\mu_{M_{2}}(d) \\
m_{2} \geq m_{1}, \\
\begin{array}{cc}
1 & l_{1} \geq u_{2}, \\
\frac{\left(l_{1}-u_{2}\right)}{\left(m_{2}-u_{2}\right)-\left(m_{1}-l_{1}\right)} \text { diğ er }
\end{array}
\end{gathered}
$$

elde edilir. Eşitlik (7)' da verilen $d, \mu_{M_{1}}$ ve $\mu_{M_{2}}$ arasındaki en yüksek kesişim noktasının ordinatıdır. $M_{1}$ ve $M_{2}$ ' yi klyaslayabilmek için $V\left(M_{2} \geq M_{1}\right)$ ve $V\left(M_{1} \geq M_{2}\right)$ değerlerinin her ikisine de ihtiyaç duyulur.

Adım 3. Konveks bir sayının $k$ tane konveks bulanık sayıdan $M_{i} i=\{1,2, \ldots, k\}$ büyük olmasının olabilirlik derecesi Eşitlik (8)'deki gibi tanımlanabilir.

$$
V\left(M \geq M_{1}, \ldots, M_{k}\right)=V[(M \geq
$$

$\left.M_{1}\right)$ ve ...ve $\left.\left(M \geq M_{k}\right)\right]=\min V\left(M \geq M_{1}\right)$ (8)

Burada $i=\{1,2, \ldots, k\} ; \quad k \neq i$ için $d^{\prime}\left(A_{i}\right)=$ $\min V\left(S_{i} \geq S_{k}\right)$ olduğu düşünülürse ağırlık vektörü Eşitlik (9)' deki şekilde elde edilir.

$$
\begin{aligned}
& W^{\prime}=\left(d^{\prime}\left(A_{1}\right), d^{\prime}\left(A_{1}\right), \ldots, d^{\prime}\left(A_{n}\right)\right)^{T} \\
i= & \{1,2, \ldots, n\}
\end{aligned}
$$

Adım 4. Ağırlık vektörleri Eşitlik (10)'daki şekilde normalize edilir.

$$
W^{\prime}=\left(\begin{array}{ll}
\left.d\left(A_{1}\right), d\left(A_{1}\right), \ldots, d\left(A_{n}\right)\right)^{T} i= \\
\{1,2, \ldots, n\}
\end{array}\right.
$$

Burada, $W$ ağırlık vektörü bulanık bir sayı değildir. Elde edilen bu ağırlıklar hiyerarşik olarak sentezlenerek nihai alternatif ağırlıklar bulunmalıdır.

Bu çalışmada, Bulanık AHP modelindeki ikili karşılaştırma matrislerinin oluşturulması için Çizelge 7' de yer alan ölçek kullanılmıştır.

Çizelge 7. Üçgen bulanık dönüşüm ölçeği

\begin{tabular}{cccc}
\hline Rakamsal değer & Dilsel ifade & Üçgen bulanık sayı & Karşılık üçgen bulanık sayı \\
\hline 1 & Eşit & $(1,1,1)$ & $(1,1,1)$ \\
2 & Zayıf üstünlük & $(1,2,3)$ & $(1 / 3,1 / 2,1)$ \\
3 & Fena değil & $(2,3,4)$ & $(1 / 4,1 / 3,1 / 2)$ \\
4 & Tercih edilir & $(3,4,5)$ & $(1 / 5,1 / 4,1 / 3)$ \\
5 & İyi & $(4,5,6)$ & $(1 / 6,1 / 5,1 / 4)$ \\
6 & Oldukça iyi & $(5,6,7)$ & $(1 / 7,1 / 6,1 / 5)$ \\
7 & Çok iyi & $(6,7,8)$ & $(1 / 9,1 / 8,1 / 6)$ \\
8 & Mutlak & $(7,8,9)$ & $(1 / 10,1 / 9,1 / 8)$ \\
9
\end{tabular}




\section{Potansiyel tarım alanlarının belirlemesi}

Kriterlerin göreceli önem seviyeleri belirlendikten sonra işlemeli potansiyel işlemeli tarım alanlarının belirlenmesinde Ağırlıklı Doğrusal Kombinasyon (weighted linear combination - WLC) yöntemi kullanılmıştır. WLC, basit toplamlı ağırlıklandırma (simple additive weighting - SAW), ağırlıklı toplama, ağırlıklı doğrusal ortalama ve ağırlıklı bindirme olarak da bilinmektedir (Malczewski and Rinner, 2015). WLC yöntemi potansiyel bir bölgenin uygunluk değerini, Eşitlik (11)'da yer alan formülü kullanılarak hesaplar. Eşitlik (11)'daS $\mathrm{i}_{\mathrm{i}}$, i bölgesinin uygunluk değerini; $\mathrm{w}_{\mathrm{k}}, \mathrm{k}$ kriterinin göreceli önem seviyesini, $\mathrm{a}_{\mathrm{ik}} \mathrm{i}$ bölgesinin $\mathrm{k}$ kriteri altındaki standart değerini ve $\mathrm{l}$ toplam kriter sayısını temsil etmektedir (Elalfy et al., 2010).

$$
\mathrm{S}_{\mathrm{i}}=\sum_{\mathrm{k}=1}^{\mathrm{l}} \mathrm{w}_{\mathrm{k}} \mathrm{a}_{\mathrm{ik}}
$$

Değerlerin sıklık dağılımı ve istatistik bilgiler göz önünde bulundurularak yapılan çalışmalar sonrasında, doğal kırınım (Natural Breaks Jenks) yöntemi ile 5 sinıfta gösterilmesi uygun değerlendirilmiştir. $\mathrm{Bu}$ yöntem, verilerin eşit dağılmadığı, değerler arası büyük farklılıkların olduğu ve sınıflar arası farklılıkların belirgin olarak sunulma ihtiyacı olduğu durumlarda kullanılmaktadır. Doğal kırınım (Jenks) yöntemi ile yapılan sınıflandırma sonuçları gösterilmiştir (Şekil 8).

Potansiyel işlemli tarım alanlarına ait uygunluk sınıfları ve bu sınıflara ait indeks değerleri ise Çizelge 8'de verilmiştir.

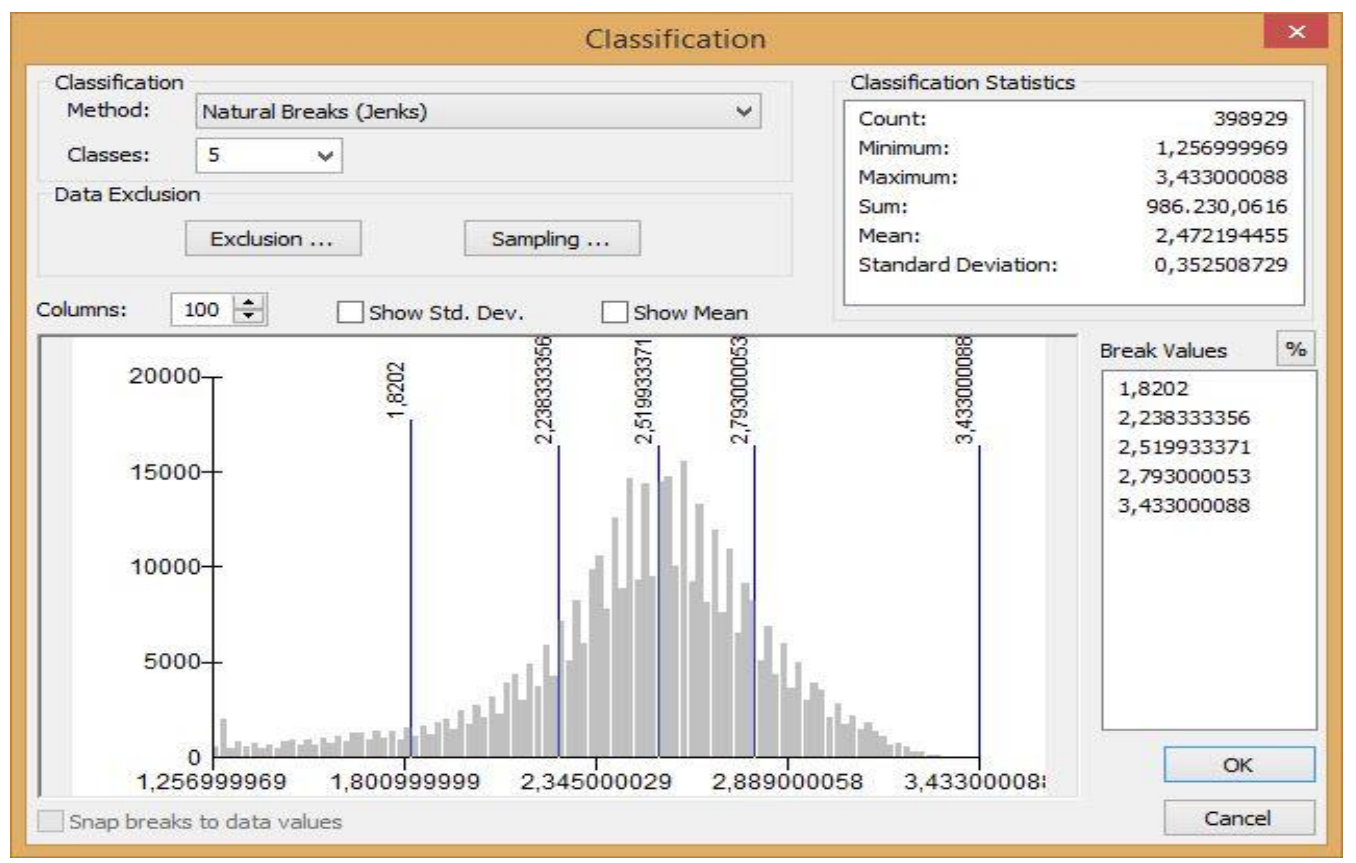

Şekil 8. Doğal kırınım (Natural Breaks Jenks) yöntemi ile 5 sınıfa ait indeks değerlerin gösterilmesi

Çizelge 8. Potansiyel işlemli tarım alanlarına ait uygunluk sınıfları ve indeks değerleri

\begin{tabular}{|l|l|c|}
\hline Sinıf & Tanımlama & İndeks Değeri \\
\hline S1 & Çok uygun & $1,25-1,82$ \\
\hline S2 & Uygun & $1,82-2,23$ \\
\hline S3 & Az uygun & $2,23-2,51$ \\
\hline N1 & Şimdilik uygun değil & $2,51-2,79$ \\
\hline N2 & Hiçbir zaman uygun değil & $2,79-3,43$ \\
\hline
\end{tabular}

BULGULAR VE TARTIŞMA

Toprakların tanımsal istatistikleri ve enterplasyon modeller

Çalışma alanından alınan 329 toprak örneğinde

7 farklı özellikleri incelenmiş ve bu özelliklerin tanımlayıcı istatistiksel hesaplamaları yapılmıştır (Çizelge 9). Normal dağılım simetrik bir dağılımdır. Normal dağılımda simetriliğin bozulma derecesine çarpıklık (skewness) denir. Dağılış sağa uzun kuyruklu ise sağa (pozitif) çarpık, sola uzun kuyruklu 
ise sola (negatif) çarpık olarak adlandırılır. Normal dağılım eğrisinin sivrilik veya yuvarlaklık derecesine basıklık (kurtosis) denir (Yıldız vd., 1998). Çizelge 9 incelendiğinde çarpıklık katsayıları HA, kil, kum ve silt normal dağılım sergilerken diğer özellikler ise normal dağılımdan uzaktır. Normal dağılımdan uzak pH negatif (sola) çarpıklı̆ga sahipken kireç ve organik madde ise pozitif (sağa) çarpıktır. Wilding
(1985), toprak özelliklerindeki değişimlerin açılanmasında önemli bir gösterge olarak kabul edilen değişkenlik katsayısını, aldığı değerlere göre düşük $(<\% 15)$, orta $(\% 15-35)$ ve yüksek $(>\% 35)$ olarak sinıflandırmaktadır (Mallants et al., 1996). Buna göre çalışma alanında kireç, kil, kum ve silt yüksek değişkenliğe sahip, $\mathrm{pH}$, HA ve OM toprak özellikleri ise düşük değişkenliktedir.

Çizelge 9. Toprakların bazı fiziksel ve kimyasal özelliklerinin tanımlayıcı istatistikleri.

\begin{tabular}{|c|c|c|c|c|c|c|c|c|}
\hline Parametre & Ort. & S.S & D.K* & Varyans & EDD & EYD & Çarpıklık** & Basıklık \\
\hline Kireç & 10,28 & 11,55 & 55,96 & 133,57 & 0,08 & 55,96 & 1,26 & 0,92 \\
\hline pH & 7,18 & 0,68 & 4,01 & 0,47 & 4,95 & 8,96 & $-0,67$ & 0,72 \\
\hline HA & 1,35 & 0,15 & 1,37 & 0,02 & 0,94 & 2,31 & 0,52 & 4,07 \\
\hline OM & 2,85 & 1,97 & 11,76 & 3,90 & 0,18 & 11,94 & 1,24 & 2,10 \\
\hline Kil & 31,72 & 13,89 & 68,36 & 192,99 & 1,08 & 69,44 & 0,34 & $-0,38$ \\
\hline Kum & 38,93 & 16,77 & 93,41 & 281,27 & 5,87 & 99,28 & 0,27 & $-0,34$ \\
\hline Silt & 29,34 & 9,35 & 64,59 & 87,43 & 0,36 & 64,95 & 0,37 & 0,49 \\
\hline
\end{tabular}

H.A: Hacim Ağırlığı, O.M: Organik Madde, Ort.: Ortalama, S.S: Standart Sapma, D.K: Değişkenlik katsayısı, EDD: En Düşük Değer, EYD: En Yüksek Değer

*Değişkenlik Katsayısı: < 15 = Düşük Değişkenlik, 15-35 = Orta Değiş̧kenlik, $>35$ = Yüksek Değişkenlik

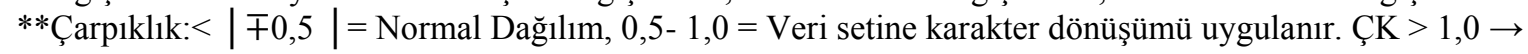
Logaritma dönüşümü uygulanır.

Ayrica ele alınan toprak parametrelerinin dağılım haritalarını oluşturmak amacıyla 15 adet enterplasyon modellerinin en düşük RMSE değerleri Çizelge 10'da verilmiştir. Buna göre OM ve HA
Basit Kriging'in Gaussian modeli uygun olarak belirlenirken $\mathrm{pH}$ ve bünye için Doğal Kriging'in Üssel modeli uygun olarak belirlenmiştir. Kireç için ise yine Basit Kriging'in Küresel modelinin uygun olduğu belirlenmiştir.

Çizelge 10. Toprak parametrelerine ait uygulanan enterplasyon modelleri ve RMSE değerleri

\begin{tabular}{|c|c|c|c|c|c|c|c|}
\hline \multirow[t]{2}{*}{ Enterpolasyon Modeler } & \multirow{2}{*}{\multicolumn{2}{|c|}{ Semivariogram modeller }} & \multicolumn{5}{|c|}{ Toprak Parametreleri } \\
\hline & & & $\mathrm{OM}$ & H.A & $\mathrm{pH}$ & Kireç & Bünye \\
\hline \multirow{3}{*}{$\begin{array}{l}\text { Ters Mesafe } \\
\text { Ağırlıklandırma (IDW) }\end{array}$} & \multicolumn{2}{|l|}{ IDW-1 } & 2,003 & 0,160 & 0,615 & 11,345 & 13,100 \\
\hline & \multicolumn{2}{|l|}{ IDW-2 } & 2,153 & 0,171 & 0,628 & 11,741 & 14,051 \\
\hline & \multicolumn{2}{|l|}{ IDW-3 } & 2,292 & 0,183 & 0,651 & 12,273 & 14,984 \\
\hline \multirow{3}{*}{$\begin{array}{l}\text { Radyal Tabanlı } \\
\text { Fonksiyon (RBF) }\end{array}$} & \multicolumn{2}{|l|}{ TPS } & 2,826 & 0,228 & 0,903 & 16,952 & 17,837 \\
\hline & \multicolumn{2}{|l|}{ CRS } & 1,987 & 0,158 & 0,613 & 11,240 & 12,873 \\
\hline & \multicolumn{2}{|l|}{ SWT } & 1,985 & 0158 & 0,615 & 11,124 & 12,857 \\
\hline \multirow{9}{*}{ Kriging } & \multirow[t]{3}{*}{ Doğal } & Gaussian & 1,979 & 0,164 & 0,627 & 0,015 & 12,804 \\
\hline & & Üssel & 1,973 & 0,164 & 0,611 & 0,012 & 12,798 \\
\hline & & Küresel & 1,977 & 0,165 & 0,617 & 0,010 & 12,799 \\
\hline & \multirow[t]{3}{*}{ Basit } & Gaussian & 1,930 & 0,155 & 0,626 & 0,008 & 13,987 \\
\hline & & Üssel & 1,935 & 0,156 & 0,622 & 0,032 & 14,029 \\
\hline & & Küresel & 1,931 & 0,156 & 0,621 & 0,019 & 13,807 \\
\hline & \multirow[t]{3}{*}{ Evrensel } & Gaussian & 1,979 & 0,164 & 0,627 & 0,015 & 12,804 \\
\hline & & Üssel & 1,973 & 0,164 & 0,612 & 0,012 & 12,798 \\
\hline & & Küresel & 1,977 & 0,165 & 0,617 & 0,010 & 12,799 \\
\hline
\end{tabular}

TPS:ThinPlateSplin, CRS: CompletelyRegularizedSpline, SWT: SplineWithTension

FAHP ile kriter ağırlıklarının belirlenmesi

$\mathrm{Bu}$ çalışmada potansiyel işlemeli tarım alanlarının belirlenmesinde kullanılan kriterlerin göreceli ağırlıklarının belirlemesinde FAHP yöntemi kullanılmıştır. Kullanılan 9 adet kriter arasında hiyerarşik bir ilişki söz konusu değildir. Karar vericilerin yaptıkları ikili karşılaştırmalar Çizelge 6' da yer alan ikili karşılaştırma ölçeği kullanılarak yapılmıştır. Karar vericilerin değerlendirmesi sonucu oluşturulan ikili karşılaştırma matrisi Çizelge 11' de yer almaktadir. 
Çizelge 11. Kriterlerin ikili karşılaştırma matrisi

\begin{tabular}{llllllllll}
\hline Kriterler & $\begin{array}{c}\text { Ana } \\
\text { materyal }\end{array}$ & Erozyon & Derinlik & Eğim & O.M & HA & Bünye & pH & Kireç \\
\hline Ana & $(1,1,1)$ & $(1 / 4,1 / 3,1 / 2)$ & $(1 / 4,1 / 3,1 / 2)$ & $(1 / 4,1 / 3,1 / 2)$ & $(1 / 4,1 / 3,1 / 2)$ & $(1 / 3,1 / 2,1)$ & $(1,2,3)$ & $(1 / 3,1 / 2,1)$ & $(1,2,3)$ \\
materyal & $(2,3,4)$ & $(1,1,1)$ & $(1,2,3)$ & $(1 / 4,1 / 3,1 / 2)$ & $(2,3,4)$ & $(2,3,4)$ & $(1,2,3)$ & $(3,4,5)$ & $(2,3,4)$ \\
Erozyon & $(2,3,4)$ & $(1 / 3,1 / 2,1)$ & $(1,1,1)$ & $(1 / 4,1 / 3,1 / 2)$ & $(2,3,4)$ & $(1,2,3)$ & $(1,2,3)$ & $(1,1,1)$ & $(1,2,3)$ \\
Derinlik & $(2,3,4)$ & $(2,3,4)$ & $(2,3,4)$ & $(1,1,1)$ & $(4,5,6)$ & $(2,3,4)$ & $(1,2,3)$ & $(3,4,5)$ & $(3,4,5)$ \\
Eğim & $(2,3,4)$ & $(1 / 4,1 / 3,1 / 2)$ & $(1 / 4,1 / 3,1 / 2)$ & $(1 / 6,1 / 5,1 / 4)$ & $(1,1,1)$ & $(2,3,4)$ & $(1 / 3,1 / 2,1)$ & $(1,2,3)$ & $(1 / 5,1 / 4,1 / 3)$ \\
O.M & $(1,2,3)$ & $(1 / 4,1 / 3,1 / 2)$ & $(1 / 3,1 / 2,1)$ & $(1 / 4,1 / 3,1 / 2)$ & $(1 / 4,1 / 3,1 / 2)$ & $(1,1,1)$ & $(1 / 4,1 / 3,1 / 2)$ & $(1,2,3)$ & $(1,2,3)$ \\
HA & $(1 / 3,1 / 2,1)$ & $(1 / 3,1 / 2,1)$ & $(1 / 3,1 / 2,1)$ & $(1 / 3,1 / 2,1)$ & $(1,2,3)$ & $(2,3,4)$ & $(1,1,1)$ & $(1,2,3)$ & $(1,2,3)$ \\
Bünye & $(1,2,3)$ & $(1 / 5,1 / 4,1 / 3)$ & $(1,1,1)$ & $(1 / 5,1 / 4,1 / 3)$ & $(1 / 3,1 / 2,1)$ & $(1 / 3,1 / 2,1)$ & $(1 / 3,1 / 2,1)$ & $(1,1,1)$ & $(1,2,3)$ \\
pH & $(1 / 3,1 / 2,1)$ & $(1 / 4,1 / 3,1 / 2)$ & $(1 / 3,1 / 2,1)$ & $(1 / 5,1 / 4,1 / 3)$ & $(3,4,5)$ & $(1 / 3,1 / 2,1)$ & $(1 / 3,1 / 2,1)$ & $(1 / 3,1 / 2,1)$ & $(1,1,1)$ \\
Kireç & & & & & & & & & \\
\hline
\end{tabular}

İkili karşılaştırmalar yapıldıktan sonra FAHP işlem adımları (Eşitlik 1-9) izlenerek Çizelge 12'de yer alan kriter ağırlıkları elde edilmiştir. Çizelge 12 'de görüldüğü gibi 0.274 ağırlık değeri ile eğim kriteri en yüksek ağırlığa sahip iken bunu erozyon ve derinlik kriterleri izlemektedir. En düşük ağırlık değeri ise 0.024 ile ana materyal kriteri olmuştur.

Çizelge 12. Potansiyel işlemeli tarım alanlarının değerlendirmesinde kullanılan kriterlerin ağırlıkları

\begin{tabular}{ll}
\hline Kriter & Ağırlık Değerleri \\
\hline Ana materyal & 0.024 \\
Erozyon & 0.221 \\
Derinlik & 0.151 \\
Eğim & 0.274 \\
O.M & 0.081 \\
H.A & 0.056 \\
Bünye & 0.120 \\
pH & 0.035 \\
Kireç & 0.038 \\
\hline
\end{tabular}

CBS teknolojisi, sorgulama ve istatistiksel analizler vb. veri tabanı prosedürlerini görselleştirmekte ve bunları haritaların sağladığı coğrafi analizlerle birleştirmektedir. CBS'de vektör ve raster olmak üzere iki tür veri yapısı vardır. Vektör verilere kıyasla, raster verileri en uygun yer analizleri gibi belirli mekânsal analizleri gerçekleştirmek için daha uygun bir yol sunar. Bu nedenle, bu çalışmadaki katmanlarda vektör veriler (jeoloji, derinlik vb) raster verilere dönüştürülmüştür.
Kriter katmanların raster veri türüne dönüştürülmesinden ve FAHP ile kriter ağırlıklarının belirlenmesinden sonra tüm katmanlar WLC yöntemi kullanılarak birleştirilmiştir. WLC yöntemi ile katmanlar birleştirilirken FAHP yöntemi sonucunda elde edilen kriter ağırlıkları kullanılmıştır. Bu çalışmada WLC yöntemi uygulanırken ArcGIS yazılımında yer alan Weighted Sum aracı kullanılmıştır.

\section{Potansiyel işlemeli tarım alanları ve AKK ile karşılaştırılması}

Erzurum iline ait potansiyel işlemeli tarım alanlarının Fuzzy-AHP yaklaşımı ile belirlenmesi sonucu uygunluk siniflarina ait alansal ve oransal dağılım Çizelge 13 ve Şekil 9 da verilmiştir. Toplam il sınırına ait alanın \%19.64'ü (488.454,2 ha) işlemeli tarıma S1 ve S2 düzeylerinde yani çok uygun ve uygun olarak belirlenirken, $\% 49.45$ ' $\mathrm{i}$ ise işlemeli tarımsal faaliyetlere uygun olmadığı belirlenmiştir. İşlemeli tarıma potansiyel olarak uygun ve çok uygun alanlar Aşkale, 1lıca, Merkez, Pasinler, Köprüköy, Horasan ilçeleri ile İlin güneyinde yer alan Tekman, Karayazı, Hınıs ve Karaçoban ilçeleri içerisinde dağılım gösterdiği görülmektedir. İlin işlemeli tarıma mevcutta veya hiç uygun olmayan (N1 ve N2) alanları ise çoğunlukla ilin batı ve kuzey batısında yer alan Ilıca, Pazaryolu, İspir ilçelerinde yaygın olarak dağılımı görülürken yer yer Tortum, Uzundere, Olur ve Şenkaya ilçelerinde de bulunmaktadır. Ayrıca \%30.91'lik kısmı ise çok az (S3) uygun olduğu belirlenmiştir.

Çizelge 13. Erzurum iline ait potansiyel işlemeli tarım alanlarına ait uygunluk sınıfları

\begin{tabular}{|c|c|c|c|c|}
\hline \multirow{2}{*}{ Sinıf } & \multirow{2}{*}{ İndeks } & \multirow{2}{*}{ Tanımlama } & \multicolumn{2}{|c|}{ Alan } \\
\cline { 3 - 4 } & & & 143841.8 & 5.78 \\
\hline S1 & $1.25-1.82$ & Çok uygun & 344612.4 & 13.86 \\
\hline S2 & $1.82-2.38$ & Uygun & 768783.0 & 30.91 \\
\hline S3 & $2.38-2.51$ & Az uygun & 834544.8 & 33.56 \\
\hline N1 & $2.51-2.79$ & Şimdilik uygun değil & 395262.8 & 15.89 \\
\hline N2 & $2.79-3.43$ & Hiçbir zaman uygun değil & 2487045 & 100.00 \\
\hline
\end{tabular}




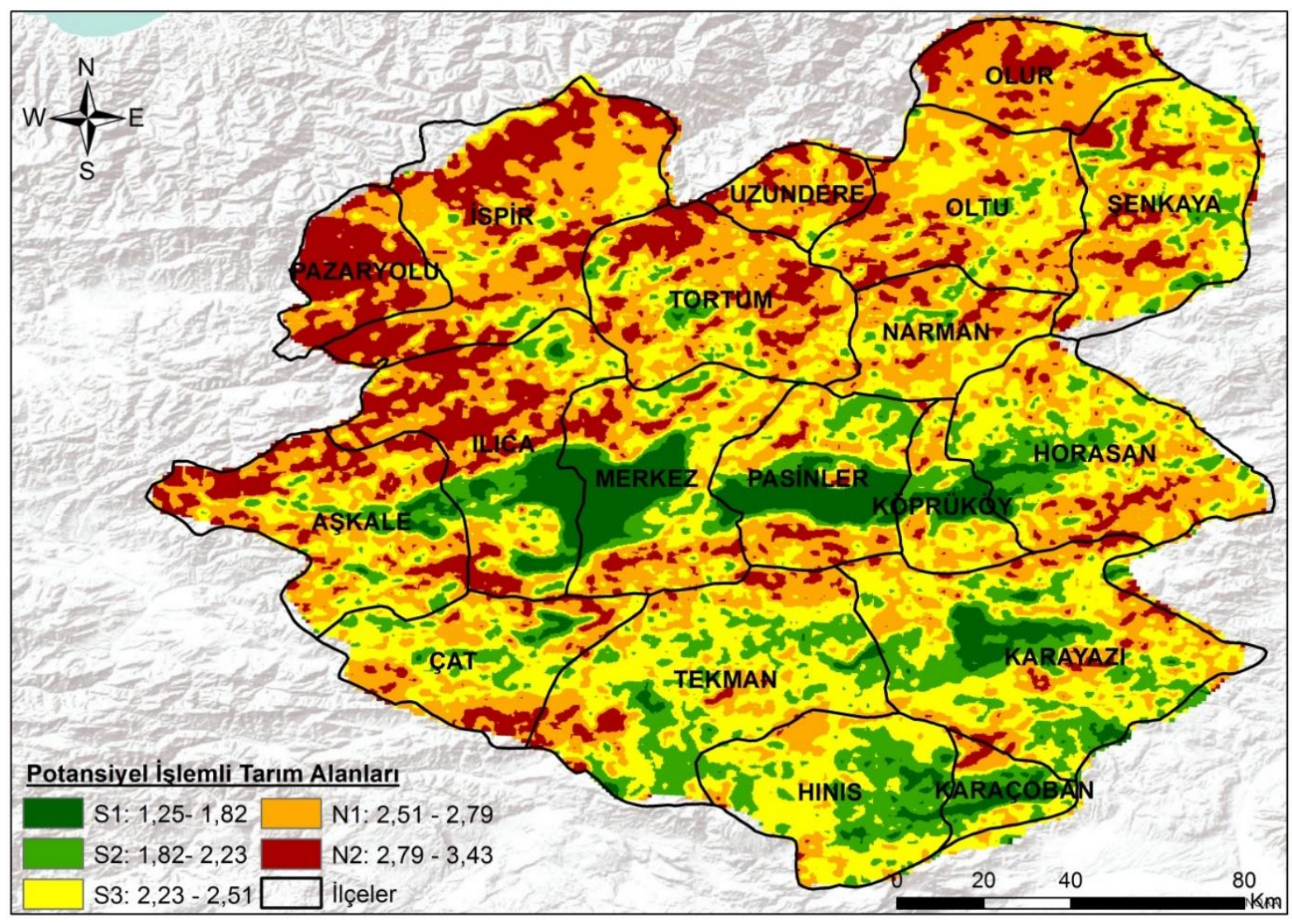

Şekil 9. Erzurum iline ait potansiyel işlemeli tarım alanlarının uygunluk sınıflarına ait dağılım haritası

İlin 1980'li y1llarda yapılmıș il envanter raporuna göre (Anonim, 1980) Arazi Kullanım Kabiliyet (AKK) sinıflarının alansal ve oransal dağılımları ile haritası Çizelge 12 ve Şekil 10'da verilmiştir. Alanın AKK sınıfına göre dağılımları ise alanın işlemeli tarıma uygun sinıfları oluşturan ilk dört sinıfın toplamı 761.499,9 ha ile toplam alanın \% 30.62'sini oluşturmaktadır. Aslında işlemeli tarım alanları için uygun olarak gösteriler IV. sınıf araziler ancak arazilerde toprakların zarar görmemeleri açısından özel tedbirler alınması sonrasında kullanılabilir. Bu durumda ilk üç sınıf işlemeli tarım alanları için çok daha fazla önem arz etmektedir ki buda toplam alanın yaklaşık \%16'sına denk gelmektedir. İlk üç sınıfa ait dağılım model ile elde edilen dağılıma yakınlık göstermekte olup, I., II. ve III. sınıfa ait alanlar Akçakale'nin bir kısmı, Ilıca, Merkez, Pasinler, Köprüköy, Horasan ilçeleri ile güneyde Karaçoban, Hınıs ve Karayazı İlçelerinde dağılım göstermektedir. Alanda V. sınıf araziler çok az dağılım göstermektedir. Buna karşın VI., VII. ve VIII. sınıf araziler toplam alanın yaklaşık \%68'ni oluşturmaktadır. Bu alanlar ise ilin özellikle kuzey, kuzeybatı ve kuzeydoğu kesimlerinde yer alan ilçelerinde yaygın olarak dağılım göstermektedir.

Modelden elde edilen veriler ile AKK sınıflarının karşılaştırılması yapılması durumunda ise, işlemeli tarıma uygun olan S1 ve S2 değerleri modelde ilin \%19.6 karşılık gelirken, AKK'nın ilk üç sınıfa ait değeri ise \%16.0 olarak belirlenmiştir. Aslına bu değerler bir birine yakın olmasına karşın modelde S3 olarak gösterilen az uygun alanlar, AKK da marjinal tarım alanları olan IV. sınıf ile karşılaştırıldığında model yaklaşık alanın \%31'i işlemeli tarıma az uygun olarak değerlendirirken, AKK'da IV. sınıf yaklaşık \%15 olarak belirlenmiş. Her iki yaklaşımda da il sınırı içerinde kalan toplam alanın yarısından fazlasının işlemeli tarıma uygun olmayan alanları oluşturduğu belirlenmiştir. 
Çizelge 12. Arazi Kullanım Kabiliyet (AKK) sınıflarının alansal ve oransal dağılımları

\begin{tabular}{|l|c|c|}
\hline \multirow{2}{*}{ AKK } & \multicolumn{2}{|c|}{ Alan } \\
\cline { 2 - 3 } & ha & $\%$ \\
\hline I sinıf & 61003,8 & 2,45 \\
\hline II sinıf & 164340,5 & 6,61 \\
\hline III sinıf & 172227,9 & 6,93 \\
\hline IV sinıf & 363927,7 & 14,63 \\
\hline V sinıf & 1109,16 & 0,04 \\
\hline VI sinıf & 449887,6 & 18,09 \\
\hline VII sinıf & 1159935 & 46,64 \\
\hline VIII sinıf & 87315,54 & 3,51 \\
\hline Diğer & 27297,66 & 1,1 \\
\hline Toplam & 2487045 & 100 \\
\hline
\end{tabular}

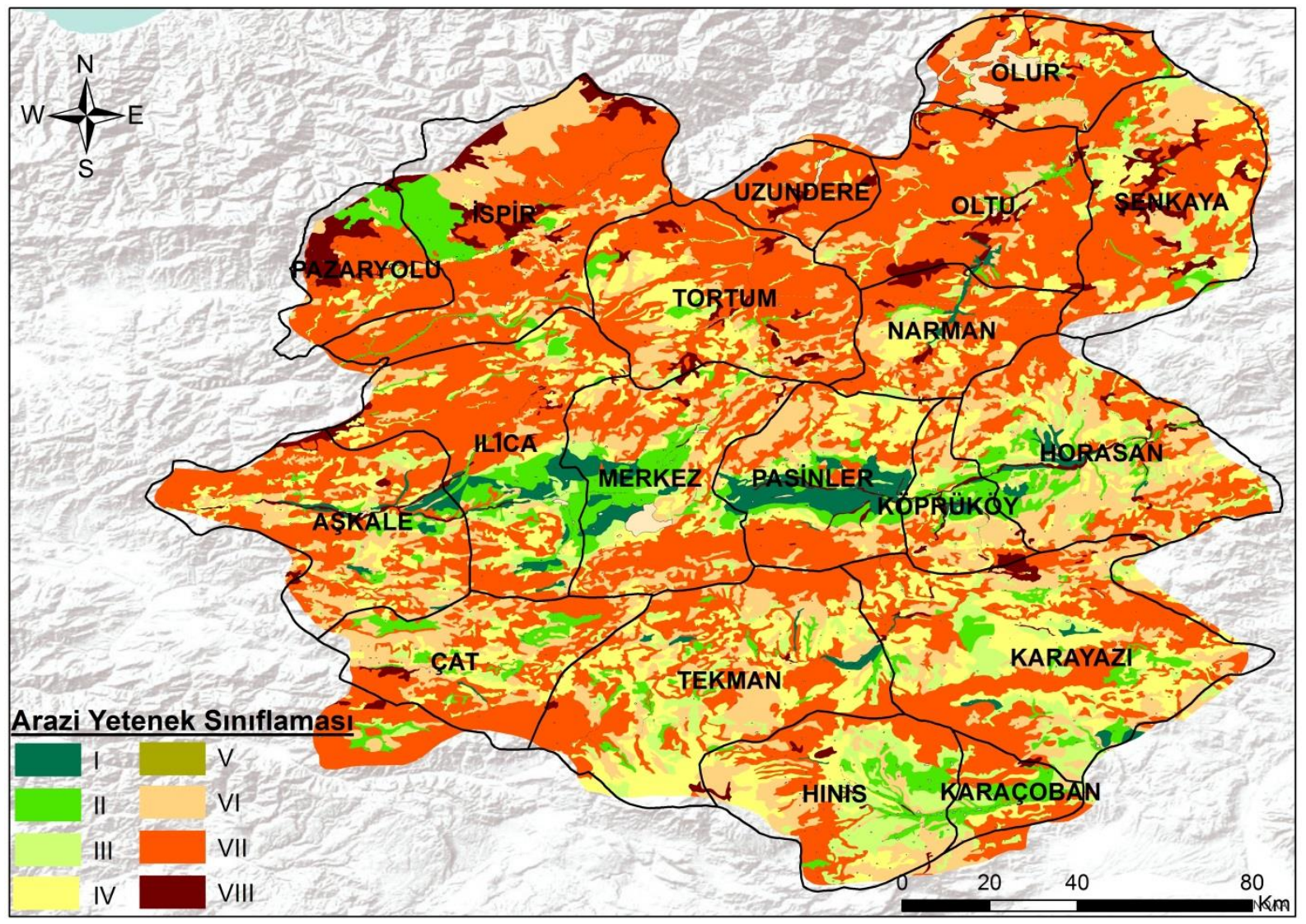

Şekil 10. Arazi Kullanım Kabiliyet (AKK) sınıflarının dağılım haritası

\section{SONUÇ}

Çalışma, Erzurum ilinin temel coğrafi özelliklerinin belirlenmesi ve AHP-Fuzzy ve CBS ortamında bindirme analiz yöntemi ile işlemeli tarıma uygun potansiyel sahaların belirlenmesini içermektedir. Ayrıca elde edilen veriler, 1980'li yıllarda Mülga Köy Hizmetleri Genel Müdürlüğünce yapılmış AKK verileri ile karşılaştırmaları yapılmıştır. $\mathrm{Bu}$ doğrultuda, çalışmanın çıkış noktasını; günümüzde kullanılan güncel teknolojiler ile (uzaktan algılama, coğrafi bilgi sistemi) yeni yaklaşım metodolojilerin (jeoistatistik, Fuzzy-AHP) yanı sıra güncel sayısal veriler (toprak, DEM-eğim, jeoloji, erozyon, arazi kullanım arazi örtüsü vb.) kullanılması ile ilin potansiyel işlemeli tarıma uygun alanların dağılımlarının ortaya konulması 
oluşturmaktadır. Elde edilen sonuca göre, Erzurum ilinin \%19.64'ü potansiyel işlemeli tarıma uygun alanlardan oluşmaktadır. Bu oran AKK da ise \%16 olarak belirlenmiştir.

Ayrıca, CBS ve UA teknikleri, yeni yöntem ve modellerle gün geçtikçe artan bir öneme sahip olmuş, mekânsal çalışmaların vazgeçilmez araçları haline gelmiştir. Toprak ve arazi gibi vazgeçilmez doğal kaynaklara ait faktörlerin çoğunda CBS ve UA tekniklerinin kullanılması, analizlerin yapılmasında ve haritaların oluşturulmasın da kolaylıklar sağlamıştır. Bu tekniğin kullanılması verilere daha kısa sürede ulaşılmasına, analiz ve sorgulama işlemi ile haritaların üretilmesine olanak tanımıştır.

\section{KAYNAKLAR}

Anonim, 1980. Toprak Kaynakları İl Envanter Raporlar1 Erzurum. TOPRAKSU Genel Müdürlüğü Yayınları, Ankara.

Arslan, H., Cemek, B., Güler, M., Yıldırım, D., 2012. Değişebilir sodyum yüzdesinin (ESP) konumsal dağılımının farklı enterpolasyon yöntemleri ile değerlendirilmesi. II. Ulusal Sulama ve Tarımsal Yapılar Sempozyumu, 24-25 Mayıs, İzmir.

Buckley, J. J., 1985. Fuzzy hierarchical analysis. Fuzzy Sets And Syst., 17 (3): 233-247.

Chang, D. Y., 1996. Applications of the extent analysis method on fuzzy AHP. European J. of Operational Research, 95 (3): 649-655.

Dağdeviren, M., 2007. Bulanık analitik hiyerarşi prosesi ile personel seçimi ve bir uygulama. Gazi Üniv. Müh.-Mim. Fak. Derg., 22 (4): 791799.

Deng, H., 1999. Multi criteria analysis with fuzzy pair wise comparison. In Fuzzy Systems Conference Proceedings, 1999 IEEE International, 2: 726-731.

Dengiz, O., Sarıolu, F.E., 2011. Samsun İlinin Potansiyel Tarım Alanlarının Genel Dağılımları ve Toprak Etüd ve Haritalama Çalışmalarının Önemi. Anadolu Tarım Bilimleri Derg., 26 (3): 241-253.

Elalfy, Z., Elhadary, R., Elashry, A., 2010. Integrating GIS and MCDM to Deal with landfill site selection. International Journal of Engineering \& Technology, 10 (6): 32-42.

FAO, 1989. Gidelines for land use planning. Inter departmental Working Group on Land Planning, FAO, Rome.

Goovaerts, P., 1998. Geostatistical tools for characterizing the spatial variability of microbiological and physico-chemical soil properties. Biology and Fertility of Soils, 27: 315-334.

Kahraman, C., Cebeci, U., Ulukan, Z., 2003. Multicriteria supplier selection using fuzzy AHP.
Logistics information management, 16 (6): 382394.

Kahraman, C., Cebeci, U., Ruan, D., 2004. Multiattribute comparison of catering service companies using fuzzy AHP: Thecase of Turkey. International Journal of Production Economics, 87 (2): 171-184.

Mallants, D., B.P. Mohanty, D. Jacques, J. Feyen., 1996. Spatial variability of hydraulic properties in a multi-layered soil profile. Soil Sci., 161 (3): 167-181.

Malczewski, J., Rinner, C., 2015. Multi criteria decision analysis in geographic information science. New York: Springer.

Mulla, D.J., McBratney, A.B., 2000. Soil Spatial Variability. In: Handbook of Soil Science (Ed. in chief: Malcom E. Summer), CRS Press, A321-A-351.

Newhall, F., Berdanier, C.R., 1996. Calculation of soil moisture regimes from the climatic record. Soil Survey Investigations Report No. 46, National Soil Survey Center, Natural Resources Conservation Service, Lincoln, NE.

Özbek, A.K., Öztaş, T., 2014. Tarım arazilerinin amaç dışı kullanımı; Erzurum örneği. Ekoloji, 13 (52): 1-6.

Renard, K.G.,Foster, G.R., Weessies, G.A., McCool, D.K., Yoder, D.C., 1997. Predicting Soil Erosion by Water: A guideto to conservation planning with the Revised Universal Soil Loss Equation (RUSLE). U.S. Department of Agriculture, Agriculture Handbook 703 p.

Saaty, T.L., 1980. The Analytic Hierarchy Process, McGraw-Hill, New York, pp. 37-85.

Taşan, M., Demir, Y., 2017. Çeltik yetiştiriciliği yapılan arazilerde demir ve mangan içeriklerinin alansal dağılımının farklı enterpolasyon yöntemleri ile belirlenmesi. Anadolu Tarım Bilim. Derg., 32: 64-73.

TÜIK, 2010. Web sitesi. Bitkisel üretim istatistikleri. http://www.tuik.gov.tr/bitkiselapp/bitkisel.zul. (Erişim Tarihi: 27 Ağustos 2018).

TÜİK, 2018. Web sitesi. Bitkisel üretim istatistikleri. http://www.tuik.gov.tr/bitkiselapp/bitkisel.zul. (Erişim Tarihi: 27 Ağustos 2018).

Van Wambeke, A.R., 2000. The Newhall Simulation Model for estimating soil moisture \& temperature regimes. Department of Crop and Soil Sci., Cornell University, Ithaca, NY.

Van Laarhoven, P.J.M., Pedrycz, W., 1983. A fuzz yextension of Saaty'spriority theory. Fuzzy set sand Systems, 11 (1-3): 229-241.

Wilding, L.P., 1985. Spatial variability: it'sdocumentation, accommodation and implicationto soil surveys. In: Soil Spatial Variability. (Eds: Nielsen, D.R. and J. Bouma) 
Erzurum İli Temel Coğrafi Özellikleri ve Potansiyel İşlemeli Tarım Alanı Varlığı

Pudoc, Wageningen, The Netherlands, pp. 166194.

Wischmeier, W.H., Smith, D.D., 1978. Predicting Rain fall Erosion Losses - A Guide for Conservation Planning. USDA, Agricultural Handbook 537. Washington.
Yıldız, N., Akbulut, Ö., Bircan, H., 1998. İstatistiğe giriş. Erzurum: Şafak Yayınevi.

Zadeh, L.A., 1965. Fuzzy Sets. Information and Control, 8: 338-353. 